Revista lus et Praxis, Año 22, No 1, 2016, pp. 271 - 322

ISSN 0717 - 2877

Universidad de Talca - Facultad de Ciencias Jurídicas y Sociales

Una revisión crítica de los efectos de la resolución por incumplimiento y una propuesta de solución Claudia Carolina Mejías Alonzo

Trabajo recibido el 6 de marzo y aprobado el 30 de junio de 2015

\title{
Una revisión crítica de los efectos de la resolución por incumplimiento y una propuesta de solución
}

\author{
A CRITICAL REVIEW OF THE TERMINATION FOR DEFAULT'S EFFECTS
}

AND THE PROPOSAL OF A NEW SOLUTION

\section{Claudia Carolina Mejías Alonzo*}

\section{RESUMEN}

En este artículo se analizan críticamente los efectos, que tradicionalmente se atribuyen a la resolución por incumplimiento, cuestionando que la retroactividad y las normas que usualmente se aplican sean coherentes con la institución. Se pretende demostrar que en la materia existe un vacío o laguna legal que siendo colmado con los principios propios del derecho civil, en concreto, el enriquecimiento sin causa, proporciona soluciones que se ajustan a la resolución como mecanismo de tutela del acreedor lesionado por el incumplimiento.

\section{ABSTRACT}

The argument of this paper focus on a critical analysis of the effects recognized to the termination for default. It questions some of them, i.e., the retroactivity and the rules applicable to this institution. The paper pretends to show that there is a gap to fill and this can be made by general principles of civil law. Specifically, the principle of unjust enrichment. This solution is according with the current view that sees resolution as a remedy.

\section{Palabras Clave}

Efectos de la resolución, Retroactividad, Incumplimiento

KEYWORDS

Effects of the resolution, Retroactivity, Breach of contract

La facultad resolutoria se encuentra consagrada, entre nosotros, en el artículo 1489 del Código civil, norma que faculta al acreedor de un contrato bilateral para demandar la resolución del contrato o su ejecución forzada, en ambos casos con derecho a ser indemnizado de los perjuicios.

Esta facultad, tradicionalmente, ha sido abordada por nuestra doctrina a propósito de una clase de obligaciones, las condicionales, debido a la ubicación del precepto legal referido; o bien, como uno de los efectos particulares de los

\footnotetext{
* Profesora de Derecho civil, Pontificia Universidad Católica de Valparaíso (Valparaíso, Chile). Correo electrónico: claudia.mejias@ucv.cl.
} 
contratos bilaterales ${ }^{1}$. La doctrina más reciente, critica este tratamiento objetando su carácter de condición y enfatiza que se trata de un mecanismo más de tutela del acreedor lesionado por el incumplimiento en un contrato bilateral. En efecto, como hemos afirmado en otra ocasión, adhiriendo a la doctrina más reciente, existen una serie de diferencias entre la facultad resolutoria y una verdadera condición resolutoria, ciertamente la más importante es aquella que entiende que el cumplimiento no puede ser considerado una condición. En la estructura de toda condición van insertos los elementos de futuridad e incertidumbre; las partes al celebrar válidamente un contrato, se rigen por esta ley privada, se predica de ella su fuerza obligatoria -exartículo 1545 del Código civil-, razón por la que la prestación debida no puede calificarse como un hecho incierto. Las diferencias se manifiestan, además, con relación a su origen, la forma en que operan, la opción que conceden, a los elementos del contrato al que pertenecen [artículo 1444 del Código civil], la manera en que produce sus efectos y la posibilidad de demandar conjuntamente una indemnización de perjuicios ${ }^{2}$.

Ciertamente ha sido el propio tenor del artículo 1489 del Código civil y la calificación que hace de la facultad resolutoria como condición, que obedece a razones históricas, lo que ha incidido en la postura tradicional de nuestra doctrina. Sin embargo, si consideramos las actuales condiciones del tráfico, que difieren claramente de aquellas que tuvo a la vista el codificador, caracterizadas por el intercambio de bienes en masa y la diversificación de los servicios, que han conllevado a que las obligaciones relevantes lo sean aquellas con objeto fungible, es decir, aquellas en las que el interés del acreedor queda satisfecho con cualquier objeto o actividad que coincida con el programa de prestación prometida al constituirse la relación obligatoria; es que es posible calificar a la resolución por incumplimiento como la facultad que tiene el acreedor para desvincularse del contrato, una vez que se dé su presupuesto, con la finalidad de poder dirigirse al mercado para buscar la forma más adecuada para satisfacer su interés lesionado -realizando una operación de reemplazo- ${ }^{3}$. Ya en el estudio

\footnotetext{
1 Reconduce su estudio a las obligaciones condicionales Alessandri (1988), pp. 195 y ss. FueYo (2004), pp. 298 y ss. Mientras que otros, a los efectos particulares de los contratos bilaterales López (2005), pp. 561-566.

2 Peñallillo (2012), pp. 9-10; Díez-Picazo (2008), pp. 810 y ss.; Clemente (1998), pp. 39 y ss.: Álvarez (1986), pp. 70 y ss.

3 Para un desarrollo de estos argumentos véase Mejías (2011). En esta dirección Clemente (1998), p. 89; FenOY (2011), p. 1574; DíEz-Picazo (2008), pp. 814-814. En la doctrina nacional destaca el efecto liberatorio Barros, quien lo menciona como una de las finalidades prácticas de la resolución, BARROS (2007), p. 419. AlCALDE (artículo inédito, gentilmente facilitado por su autor), pp. 3-4, en este sentido afirma que es el efecto propiamente jurídico cuya única consecuencia es la liberación del acreedor frustrado y la extinción de las obligaciones recíprocas y de los efectos inherentes a la relación contractual.
} 
mismo de esta facultad, la doctrina se ha ocupado de precisar los requisitos que determinan su procedencia, en especial, la gravedad del incumplimiento que se requiere para que el acreedor pueda poner término al contrato y, con ello, dejar de lado la fuerza obligatoria del $\mathrm{mismo}^{4}$. Sin embargo, han sido escasamente tratados los efectos que produce, en concreto, el efecto retroactivo que se le atribuye y sobre esto pretendemos ahondar en el presente artículo ${ }^{5}$. Nos centraremos primero, en una exposición crítica acerca del estado de la cuestión en la doctrina nacional para luego proponer una re-lectura de las normas concernidas a propósito de sus efectos. Finalizaremos con un cuerpo de conclusiones.

\section{El estado de la cuestión: los efectos de la denominada condición resolutoria tácita en la doctrina nacional}

En materia de efectos de la resolución por incumplimiento lo primero que podemos constatar es que el tratamiento que la doctrina nacional brinda es disímil. Así, parte de los autores no contienen una referencia expresa a estos en el desarrollo directo de la denominada condición resolutoria tácita y se limitan a señalar que ella opera en virtud de una sentencia judicial, para luego enunciar las diferencias que presenta con la condición resolutoria ordinaria ${ }^{6}$. Otros, luego del tratamiento del pacto comisorio y sus particularidades, abordan los efectos de la condición cumplida, sin que se precise necesariamente si se aplican a todas ellas -condición resolutoria ordinaria, tácita o pacto comisorio ${ }^{7}$-, o a alguna. Sin embargo, fácilmente se advierte la coincidencia, con lo enunciado a propósito de la condición resolutoria ordinaria y existiendo consenso en la doctrina nacional en que el pacto comisorio equivale a la condición resolu-

\footnotetext{
${ }^{4}$ Sobre las diversas posturas que ha asumido nuestra doctrina y jurisprudencia sobre el particular, véase Mej́́As (2011).

${ }^{5}$ Recientemente, Pizarro (2010), pp. 449-460 y Bécar (2010), pp. 133-152.

${ }^{6}$ FueYo (1958), pp. 126-127; 138-144. El autor hace presente, más adelante, el tradicional paralelo entre estas condiciones considerando: si opera o no de pleno derecho, si cabe pedir el cumplimiento y menciona con relación a sus efectos: "en la condición resolutoria ordinaria no es posible evitar los efectos propios de la condición cumplida. Sin embargo, en la tácita puede enervarse la acción de resolución mediante el cumplimiento". El autor, en rigor, no se centra en los efectos que produciría la facultad del artículo 1489 del Código civil sino en la posibilidad de enervarla mediante el pago, aplicando la regla prevista en el artículo 310 del Código de procedimiento civil, posibilidad que entendemos no se condice con la facultad que detenta el acreedor, sobre el particular, véase MejíAs (2012), pp. 84-86.

7 Así, por ejemplo, el profesor Abeliuk afirma a propósito de la condición resolutoria ordinaria que no se referirá ahora a sus efectos sino luego de haber estudiado las restantes categorías de condición resolutoria "porque son los mismos para todas las resolutorias, y difieren solamente en cuanto a la forma en que operan". AвELIuk (2010), p. 506, y esto lo reitera más adelante, p. 538.
} 
toria tácita expresa, es posible colegir que su ámbito de aplicación es común a todas ellas ${ }^{8}$. Excepcionalmente, se abordan genéricamente los efectos de la resolución, afirmándose que ellos operan con efecto retroactivo y que "son los mismos en cualquiera de las formas o modalidades que reviste la condición resolutoria. En otros términos no hay diferencia entre la condición subentendida en los contratos bilaterales y el pacto comisorio con la condición resolutoria en la manera en que obran" ${ }^{\prime 9}$. Consignamos finalmente, que parte de la doctrina, contiene una remisión tangencial a estos efectos, a propósito de la ineficacia de los actos jurídicos en sentido estricto ${ }^{10}$.

La premisa genérica de la que parte la doctrina y la jurisprudencia nacional en la materia es que cumplida la condición, la resolución debe ser declarada judicialmente y, como consecuencia de esto, es necesario colocar a las partes en la misma situación en la que se encontraban antes de la celebración del contrato, como si este jamás hubiese existido. De esta forma "la sentencia que declara resuelto el contrato por incumplimiento de uno de los contratantes reconoce un estado jurídico preexistente, y revocando, y borrando todas consecuencias del contrato, obra, ex tunc, el aniquilamiento del contrato mismo"111. Es a propósito del estudio de estos efectos que los autores distinguen la situación de las partes y la de los terceros. A continuación, nos detendremos en su análisis.

\subsection{Efectos de la resolución judicialmente declarada entre las partes}

Situados en los efectos con relación a las partes, lo primero que es menester distinguir es si las obligaciones se encuentran cumplidas o no. Si estas no se han cumplido, la doctrina, a partir de lo dispuesto en el artículo 1567 № 9 del Código civil, que prevé al evento de la condición resolutoria dentro de los modos de extinguir, afirma que las obligaciones se han extinguido.

Si se han cumplido se suele destacar el tenor del artículo 1487 del Código civil que dispone: "Cumplida la condición resolutoria, deberá restituirse lo que se hubiere recibido bajo tal condición, a menos que ésta haya sido puesta a favor del acreedor exclusivamente, en cuyo caso podrá éste, si quiere, renunciarla, pero será obligado a declarar su determinación, si el deudor lo exigiere". Se

\footnotetext{
${ }^{8}$ Véase Fueyo (1958), pp. 114-119 y pp. 138 y ss. Don Luis Claro Solar, por su parte, en el tratamiento de la condición resolutoria tácita afirma que produce los mismos efectos que la condición resolutoria ordinaria. ClaRo (1978), p. 195.

${ }_{9}^{9}$ Vío (1945), p. 374

10 Alessandri et al. (1998), pp. 320, 350-351.

11 Por todos véase Claro (1978), p. 195, previamente en las pp. 128 y ss. En la jurisprudencia, expresamente en el mismo sentido, Corte Suprema, Rol No 7973-2013, de 9 de septiembre de 2013.
} 
resalta de esta norma el carácter retroactivo con que opera la condición resolutoria cumplida, mas como suele ponerse de relieve esto es sólo en algunos casos, de allí que la regla, como lo precisaremos en el análisis de las normas respectivas, es matizada ${ }^{12}$. Nos parece relevante hacer presente que aun cuando el artículo 1487 del Código civil fuese aplicable a los efectos de la resolución por incumplimiento, cuestión que nos parece discutible, es una norma que solo consagra expresamente efectos restitutorios y no efectos retroactivos, como claramente lo disponían los proyectos de Código civil (1841-1847 y 1853) que establecían que cumplida la condición resolutoria "expresa" el contrato por el solo efecto de ella se reputa no haber existido jamás ${ }^{13}$.

A partir del efecto retroactivo se afirma, por los autores, que deben desaparecer las consecuencias de un acto jurídico que nació como si fuera puro y simple ${ }^{14}$, de manera que las cosas deben restituirse y volver a sus dueños como si estos nunca hubieran dejado de serlo ${ }^{15}$. En la misma dirección, se ha afirmado que en virtud de este principio y por una ficción legal, desaparece el estado de pendencia como si nunca hubiera existido y, en consecuencia, todos los actos realizados por el deudor en el tiempo intermedio ${ }^{16}$. Esta retroactividad se proyecta hasta el momento de la celebración del acto o contrato condicional o, como se sostiene, desde la ejecución de las prestaciones, que en el modelo clásico de contrato de ejecución instantánea y simultánea coincide con la celebración del mismo $^{17}$. Incluso parte de la doctrina nacional equipara los efectos retroactivos que se predican de la resolución a los que derivan de la nulidad judicialmente declarada ${ }^{18}$. En la misma línea se han pronunciado nuestros tribunales ${ }^{19}$.

\footnotetext{
12 En este sentido Fuero (1958), pp. 138 y ss.; Peñallillo (2012), p. 46.

${ }^{13}$ En el proyecto de Código Civil (1841-1847), en el libro relativo a los contratos y obligaciones convencionales, en su título III dedicado a las obligaciones condicionales, su artículo 13 consagra este efecto a la condición resolutoria expresa. Confróntese Bello (1887), pp. 149-150. En el Proyecto de Código civil de 1853, su artículo 1664 lo consagra en los mismos términos, sólo suprime el término "expresa", indicándose por don Andrés Bello como fuentes de su inciso $2^{\circ}$ al Código Civil con el comentario de Rogron. Bello (1887), pp. 393-394.

${ }^{14}$ Fueyo (1958), p. 116.

15 Vío (1945), pp. 374-375.

${ }^{16}$ АвеLIUк (2010), p. 494.

17 Confróntese Hinostrosa (2008), p. 479.

18 Por todos véase Vío (1945), p. 368.

19 Así nuestra Corte Suprema ha resuelto "Cabe tener en cuenta que, una vez declarada, la condición resolutoria produce efectos retroactivos, volviendo a las partes al estado jurídico en el que se encontraban previo a contratar, como si no hubiesen convenido "salvaguardando los alcances particulares de los contratos de tracto sucesivo", como expresa el profesor Claro Solar: "revocando, borrando todas las consecuencias del contrato" ("Explicaciones de Derecho Civil Chileno y Comparado", Imprenta
} 
Con relación a la forma en que ha de efectuarse esta restitución se suele acudir a reglas que se estiman comunes a todas las condiciones, incluyéndose por tanto las condiciones suspensivas y resolutorias ${ }^{20}$, sin hacerse mayor cuestión acerca de las implicancias de esto, a pesar que del tenor de algunas de estas disposiciones deja de manifiesto su difícil o nula aplicación a las condiciones resolutorias y, más aún, a la facultad resolutoria cuando opera ${ }^{21}$, que claramente no es un condición. Esto es lo que pretendemos demostrar en las líneas que siguen, ya que entendemos que los efectos restitutorios difieren del efecto retroactivo y que la materia debe estar regida por el principio del enriquecimiento sin causa.

En concreto, en nuestra doctrina, se afirma:

\section{a. En materia de aumentos y mejoras}

Los aumentos y mejoras pertenecen al acreedor, sin aumento del precio. Esta regla se desprende del tenor del artículo 1486 del Código civil, en particular de su inciso $2^{\circ}$ que dispone: "Si la cosa existe al tiempo de cumplirse la condición, se debe en el estado en que se encuentre, aprovechándose el acreedor de los aumentos o mejoras que haya recibido la cosa, sin estar obligado a dar más por ella, y sufriendo su deterioro o disminución, sin derecho alguno a que se le rebaje el precio; salvo que el deterioro o disminución proceda de culpa del deudor; en cuyo caso el acreedor podrá pedir o que se rescinda el contrato o que se le entregue la cosa, y además de lo uno o lo otro tendrá derecho a indemnización de perjuicios".

La doctrina considera que esta disposición es un claro reflejo de la retroactividad de la condición cumplida. Solución si tratándose de las mejoras se califica de injusta, contraria al principio del enriquecimiento sin causa y a las reglas que el legislador ha sentado en materia de acción reivindicatoria ${ }^{22}$-situación que se estima semejante-, ya que a propósito de las prestaciones mutuas, dispone

Nascimento, p. 195). Pues bien, declarada como ha sido la resolución del contrato celebrado entre quienes ahora litigan, se ha impuesto la necesidad de que las partes queden restituidas al estatus jurídico que tenían antes de convenir. Considerando octavo, Corte Suprema, Rol № 7973-2013, de 9 de septiembre de 2013.

${ }^{20}$ Por todos, Abeliuk (2010), pp. 538 y ss.

${ }^{21}$ El profesor Abeliuk sí sostiene que hay ligeras diferencias tratándose de un contrato bilateral, especialmente en cuanto a las obligaciones del acreedor, ya que podría operar la excepción de contrato no cumplido o la restitución ser parcial, si el incumplimiento es también parcial. Confróntese ABELIuk (2010), p. 539. Sin embargo, el autor no se pronuncia acerca del alcance de las disposiciones referidas a la forma de efectuar la restitución.

22 Aвeliuk (2010), p. 468. 
que siempre deben ser indemnizadas las mejoras necesarias, incluso al poseedor de mala $\mathrm{fe}^{23}$. La justificación de lo anterior descansa en que estas mejoras "aseguran la conservación de la cosa, las que de no realizarse producen su deterioro, menoscabo o pérdida" ${ }^{24}$, de manera que de todas formas al acreedor condicional las habría tenido que realizar.

Nosotros consideramos que esta disposición encuentra su justificación en la estructura de las condiciones suspensivas. Es más, precisa la norma en su inciso 10: "Si antes del cumplimiento de la condición la cosa prometida perece sin culpa del deudor, se extingue la obligación; y por culpa del deudor, el deudor es obligado al precio, y a la indemnización de perjuicios". Nos parece que la referencia a una cosa prometida que perece antes del cumplimiento de la condición se explica sin inconveniente tratándose de una condición suspensiva, aquel hecho futuro e incierto del que depende el nacimiento del derecho y de la obligación correlativa, mas no de una condición resolutoria, la que por su naturaleza conlleva la extinción de un derecho y, menos aún, pensando en el supuesto de procedencia de la facultad resolutoria -un incumplimiento grave-. Reafirma lo anterior el inciso segundo de la norma que analizaremos en el apartado siguiente.

Sin perjuicio de no considerar a la facultad resolutoria como una verdadera condición, no debe perderse de vista que, si esta regla se refiere solo a las condiciones suspensivas, existen otras que sientan reglas opuestas en hipótesis claras de condiciones resolutorias, casos en los que expresamente se prevé que junto con la restitución de la cosa se incluyen sus accesiones naturales y el abono de las mejoras -aun cuando el criterio seguido por el legislador no siempre es el mismo-. Así en el caso del pacto de retroventa, el artículo 1883 del Código civil obliga al comprador a restituir la cosa vendida con sus accesiones naturales, a indemnizarle los deterioros que sean imputables a su hecho o culpa y, al vendedor, al pago de las expensas necesarias ${ }^{25}$. En materia de resolución en la compraventa, el artículo 1875 inciso tercero ${ }^{26}$ del Código

\footnotetext{
${ }^{23}$ Véase los artículos 907 inciso final y 908 del Código civil.

${ }^{24}$ Alessandri y Somarriva (2005), pp. 297 y ss.

${ }^{25}$ El artículo 1883 del Código civil dispone: "El vendedor tendrá derecho a que el comprador le restituya la cosa vendida con sus accesiones naturales.

Tendrá asimismo derecho a ser indemnizado de los deterioros imputables a hecho o culpa del comprador. Será obligado al pago de las expensas necesarias, pero no de las invertidas en mejoras útiles o voluptuarias que se hayan hecho sin su consentimiento".

${ }^{26}$ El artículo 1875, inciso $3^{\circ}$ del Código civil dispone: "Para el abono de las expensas al comprador, y de los deterioros al vendedor, se considerará al primero como poseedor de mala fe, a menos que pruebe haber sufrido en su fortuna, y sin culpa de su parte, menoscabos tan grandes que le hayan hecho imposible cumplir lo pactado".
} 
civil prevé que para el abono de las expensas al comprador y de deterioros al vendedor se considerará al primero como poseedor de mala fe y, la doctrina entiende, que no pueden ser otras que aquellas que consigna el artículo 908 del Código civil, es decir, las invertidas en mejoras o reparaciones necesarias o invertidas en obras permanentes pero reducidas al valor que tengan al tiempo de su restitución ${ }^{27}$. Finalmente, a propósito del fideicomiso, el artículo 756 del Código civil ${ }^{28}$ establece a favor del propietario fiduciario, una vez cumplida la condición, que se le reembolsen las expensas extraordinarias, siguiéndose las reglas que la norma estipula. Ciertamente de estas disposiciones no es posible afirmar que exista un criterio único a seguir al momento de efectuar la restitución de las mejoras, pero de todas ellas sí es posible colegir que las expensas necesarias, ya ordinarias o extraordinarias ${ }^{29}$, deben ser restituidas, guardando coherencia con el principio rector en la materia: evitar un enriquecimiento sin causa, toda vez que el dueño de la cosa de todas formas las hubiese tenido que realizar.

\section{b. Las disminuciones y deterioros de la cosa}

Las disminuciones y deterioros los sufre el acreedor, sin tener derecho a rebaja alguna, salvo culpa del deudor. Esta regla también se basa en el inciso segundo del artículo 1486 del Código civil que ya transcribimos.

La doctrina afirma que si la pérdida es parcial y fortuita, a partir de esta disposición y en consonancia con lo dispuesto en el artículo 1550 del Código civil y el principio de retroactividad que informa la materia, la pérdida la sufre íntegramente el acreedor. Si la pérdida o deterioro es culpable, se vuelve a las reglas generales, otorgándose al acreedor el derecho alternativo que se prevé en

\footnotetext{
27 Alessandri (2003), p. 567.

${ }^{28}$ El artículo 756 del Código civil dispone: "Es obligado a todas las expensas extraordinarias para la conservación de la cosa, incluso el pago de las deudas y de las hipotecas a que estuviere afecta; pero llegado el caso de la restitución, tendrá derecho a que previamente se le reembolsen por el fideicomisario dichas expensas, reducidas a lo que con mediana inteligencia y cuidado debieron costar, y con las rebajas que van a expresarse:

$1^{\circ}$. Si se han invertido en obras materiales, como diques, puentes, paredes, no se le reembolsará en razón de estas obras, sino lo que valgan al tiempo de la restitución;

$2^{\circ}$. Si se han invertido en objetos inmateriales, como el pago de una hipoteca, o las costas de un pleito que no hubiera podido dejar de sostenerse sin comprometer los derechos del fideicomisario, se rebajará de lo que hayan costado estos objetos una vigésima parte por cada año de los que desde entonces hubieren transcurrido hasta el día de la restitución; y si hubieren transcurrido más de veinte, nada se deberá por esta causa".

${ }^{29}$ Son expensas necesarias ordinarias aquellas que se realizan periódicamente y son indispensables para la conservación de la cosa. Extraordinarias, aquellas que ocurren por una vez o a largos intervalos y que conciernen a la permanente utilidad de la cosa. Confróntese AlESSANDRI y SOMARRIVA (2005), pp. 297-299.
} 
el artículo 1489 del Código civil ${ }^{30}$. Nos parece que lo último refleja claramente que el artículo 1486 del Código civil no ha sido previsto para ser aplicado en hipótesis de ejercicio de la facultad resolutoria, ex artículo 1489, lo que queda de manifiesto si se piensa en la resolución de un contrato de compraventa de un bien raíz, decretada esta, será necesario proceder a las restituciones, el comprador de la cosa y el vendedor del precio; pero si la cosa se deteriora parcialmente por culpa del comprador, el vendedor tendría el derecho alternativo del artículo 1489. Situaciones como la descrita, carecerían de sentido.

Razones históricas, además, nos permiten entender que esta disposición ha sido concebida en la estructura propia de las obligaciones sujetas a condición suspensiva. En el proyecto de Código civil (1841-1847), en el libro relativo a los contratos y obligaciones convencionales, en su título III dedicado a las obligaciones condicionales, el artículo 12 preveía estas consecuencias en materia de aumentos, mejoras y deterioros acotadas a las obligaciones sujetas a condición suspensiva. En efecto, se establecía: "Si ántes del cumplimiento de la condición suspensiva la cosa prometida perece sin culpa del deudor, el contrato se reputará no haber existido jamás; i si por culpa del deudor, el deudor es obligado al precio i a la indemnización de perjuicios; i si la cosa no perece, sino solo se deteriora, el acreedor deberá tomarla en el estado en que se halle sin saneamiento del deterioro; salvo que el deterioro proceda de culpa del deudor, en cuyo caso el acreedor podrá pedir o que se rescinda el contrato, o que se le entregue la cosa; i ademas tendrá derecho a indemnización de perjuicios" ${ }^{\prime \prime 1}$. Su artículo siguiente, reglaba los efectos de la condición resolutoria expresa cumplida, que es el antecedente del artículo 1487 del Código civil.

En el proyecto del Código civil del año 1853, en el libro IV dedicado a los contratos y las obligaciones condicionales, su título III, vuelve a estar dedicado a las obligaciones condicionales. En su artículo 1663 inciso segundo se advierten modificaciones en la redacción del proyecto recién referido, pues se suprime de su encabezado la referencia a las condiciones suspensivas cumplidas y se alude simplemente al momento previo al cumplimiento de la condición; tampoco se alude a la extinción del contrato sino a la extinción de la obligación y se incorpora la regulación de los aumentos y/o mejoras que puede tener la cosa. La disposición establece en su inciso primero: "Si la cosa existe al tiempo de cumplirse la condicion, se debe en el estado en que se encuentre, aprovechándose el acreedor de los aumentos o mejoras que haya recibido la cosa, sin estar obligado a dar mas por ella, i sufriendo su deterioro o diminucion, sin derecho alguno a que se le rebaje

30 Abeliuk (2010), p. 499.

31 Bello, (1887), p. 149. 
el precio; salvo que el deterioro o diminucion proceda de culpa del deudor; en cuyo caso el acreedor podrá pedir que se rescinda el contrato, i, sea que acepte o no la cosa, tendrá derecho a indemnizacion de perjuicios ${ }^{\prime \prime 2}$.

Se advierte que la actual redacción del artículo 1486 inciso segundo del Código civil es prácticamente idéntica a la transcrita, norma que no fue modificada en el Proyecto Inédito, razón por la que nos parece relevante indagar en las fuentes que en el proyecto se indican, en concreto "Pothier, Oblig., 219; C.F., 1182", tendiendo claro sí que el reenvío expreso es a partir del inciso primero de la disposición y no del segundo, mas nos parece que sirve para ilustrar el campo de aplicación de la referida disposición. Pothier en su tratado de obligaciones en lo pertinente a la materia, claramente está aludiendo a las obligaciones sujetas a condición suspensiva. El apartado 218 refiriéndose a los efectos los acota a la condición suspensiva, al indicar que el efecto "es el de suspender la obligación hasta tanto que la condición se haya cumplido (...). El apartado 219, no deja duda de que la explicación es solo aplicable a las condiciones suspensivas, ya que entiende Pothier que, si la cosa que es objeto de la obligación condicional perece enteramente antes del cumplimiento, resulta innecesario esperar al cumplimiento de la obligación porque de todas formas esa condición no puede confirmar la obligación de una cosa que no existe porque carecería de objeto. Esta situación problemática, desde la perspectiva del objeto, no se presenta en los casos en que la obligación está sujeta a una condición resolutoria" ${ }^{33}$. Inmediatamente agrega Pothier "Si la cosa existe al tiempo del cumplimiento de la condición, el cumplimiento de la condición tiene ese efecto, que la cosa es debida en el estado en que se encuentre: el acreedor aprovecha el aumento sobrevenido a la cosa, si es que ha aumentado, y sufre el deterioro o disminución que ha sobrevenido, con tal que no haya sobrevenido por falta del deudor ${ }^{\prime \prime 34}$. En el apartado siguiente Pothier afirma la retroactividad en el cumplimiento de la condición, para justificar que la adquisición del derecho que resulta del compromiso se produce desde el tiempo del contrato. Pothier en el artículo II, aparado 224 y siguientes, recién aborda la temática de las condiciones resolutorias ${ }^{35}$. Por su parte, el artículo 1182 del Código civil francés acota claramente la temática a las obligaciones sujetas a condición suspensiva de su tenor y su ubicación -"Paragraphe 2: De la condition suspensive", la norma dispone: "Lorsque l'obligation a été contractée sous une condition suspensive,

\footnotetext{
32 Bello (1887), pp. 375-376.

33 Confróntese, POTHIER (1939), p. 128.

34 Pothier (1939), p. 128.

35 POthier (1939), pp. 130 y ss.
} 
la chose qui fait la matière de la convention demeure aux risques du débiteur qui ne s'est obligé de la livrer que dans le cas de l'événement de la condition.

Si la chose est entièrement périe sans la faute du débiteur, I'obligation est éteinte.

Si la chose s'est détériorée sans la faute du débiteur, le créancier a le choix ou de résoudre l'obligation, ou d'exiger la chose dans l'état où elle se trouve, sans diminution du prix.

Si la chose s'est détériorée par la faute du débiteur, le créancier a le droit ou de résoudre l'obligation, ou d'exiger la chose dans l'état où elle se trouve, avec des dommages et intérêts" ${ }^{\prime \prime 6}$.

Por lo expuesto nos parece que el tenor del artículo 1486 del Código civil fue concebido en la estructura de una condición suspensiva.

Continuando nuestro análisis en materia de disminuciones y deterioros de la cosa, estimamos pertinente traer a colación dos disposiciones, una que se centra en la resolución basada en el incumplimiento contractual y, la otra, vinculada a las restituciones que las partes deben hacerse fundada en el pacto entre ellas. Estas normas sientan, a nuestro juicio, la misma regla: el deudor es responsable de los deterioros de la cosa que debe restituir que obedecen a su hecho o culpa, mas nos parece necesario realizar algunas precisiones.

En el primer caso, nos situamos en el contrato de compraventa. Cabe recordar que conforme a la regla del artículo 1875 del Código civil el comprador es considerado como poseedor de mala fe para el abono de los deterioros al vendedor y, a partir de esto, la doctrina trae a colación el artículo 906 del Código civil, relativo a las prestaciones mutuas en la acción reivindicatoria, en virtud del cual el poseedor de mala fe es responsable de los deterioros que por su hecho o culpa haya sufrido la $\operatorname{cosa}^{37}$. Esta es una regla especial que en lo medular reitera la regla que prevé el artículo 1486 del Código civil, se es

\footnotetext{
36 "Cuando la obligación se haya contraído bajo una condición suspensiva, la cosa que constituya la materia de la obligación quedará bajo riesgo del deudor que sólo se haya obligado a entregarla en el caso del cumplimiento de la condición.

Si la cosa hubiera perecido sin mediar culpa del deudor, la obligación quedará extinguida.

Si la cosa se hubiera deteriorado sin mediar culpa del deudor, el acreedor podrá elegir entre resolver la obligación o exigir la cosa en el estado en que se encuentre, sin disminución del precio.

Si la cosa se hubiera deteriorado por culpa del deudor, el acreedor tendrá derecho a resolver la obligación o a exigir la cosa en el estado en que se encuentre, con indemnización por daños y perjuicios" (versión Legifrance).

Cabe tener presente que el artículo 1122 del Código civil español también acota estas consecuencias, en términos equivalentes a los previstos por el artículo 1486 de nuestro Código civil, a las obligaciones sujetas a condición suspensiva, sin perjuicio de la remisión que el artículo 1123 efectúa a esta disposición para las condiciones resolutorias en las obligaciones de dar.
}

37 Alessandri (2003), p. 562. 
responsable de los deterioros, a partir de la relación de ambas disposiciones, si este se ha producido por culpa del deudor. Es una regla especial porque se inserta en el contrato de compraventa y más concretamente, a propósito de la resolución por el no pago del precio. En la estructura de este contrato, siendo el pago del precio la prestación típica a cargo del comprador, nos parece razonable que el legislador equipare el incumplimiento culpable a la mala fe del comprador porque si este no se encontraba en condiciones de pagar el precio importa que ha celebrado a sabiendas un contrato que no podrá cumplir, lo que ciertamente es reñido con la buena fe. Es precisamente por lo anterior que para el legislador cesa la mala fe si prueba "haber sufrido en su fortuna, y sin culpa de su parte, menoscabos tan grandes que le hayan hecho imposible cumplir con lo pactado".

Resulta importante la precisión anterior porque no compartimos con quienes postulan que en la resolución por incumplimiento, para efectos de determinar los efectos con relación a las partes, la culpa del deudor es equivalente a la mala fe, haciendo extensiva esta regla y, a partir de ella, aplicar automáticamente las normas de la acción reivindicatoria como si se tratase de un poseedor de mala $\mathrm{fe}^{38}$. Como es sabido en materia contractual el incumplimiento se presume culpable, ex artículo 1547 del Código civil, de manera entonces que cada vez que exista un incumplimiento habría que presumir la mala fe lo que, nos parece, va en abierta contradicción con la presunción general de buena fe por la que se rigen todas las relaciones ante el derecho -ex artículo 707 del Código civil-; sin perjuicio de otros problemas adicionales como aquellos en que ninguna de las dos partes cumple, supuesto en el que entendemos es procedente la resolución, como veremos más adelante, y en la que habría que concluir que ambos están de mala fe ${ }^{39}$. Compartimos lo afirmado por Boetsch en orden a que "si estimamos que todo actuar culposo es contrario a la buena fe, y por tanto es constitutivo de mala fe, nos veríamos en la obligación lógica de afirmar que actúa de buena fe sólo quien obra de manera diligente, lo cual no nos parece acertado, porque los valores ético-sociales de lealtad, rectitud que envuelven la buena fe van más allá, y por lo tanto, son distintos de la diligencia o cuidado que señala el artículo $44^{\prime \prime 4}$. Cosa distinta nos parece es entender que en caso de deterioro culpable de la cosa que debe ser restituida, el deudor es responsable,

\footnotetext{
38 Alcalde, pp. 20 y ss.

${ }^{39}$ En el derecho español da cuenta de la dificultad de aplicar a la resolución por incumplimiento la distinción entre poseedores de buena y mala fe en materia de frutos e intereses Clemente (1998), pp. 512-515.

40 BoetsCh (2011), p. 167.
} 
responsabilidad que, a nuestro juicio teniendo en consideración el artículo 1672, se traduce en una indemnización de perjuicios por el menor valor de la cosa.

En el segundo caso, nos situamos en el pacto de retroventa. En virtud de este pacto el vendedor se reserva la facultad de recobrar la cosa vendida, estando sí obligado a pagar al comprador la suma estipulada o el precio de la venta (artículo 1881 del Código civil). El artículo 1883 prevé como derechos del comprador, la restitución de la cosa vendida con sus accesiones naturales y la indemnización por los deterioros de la cosa que se deban a hecho o culpa del vendedor. Creemos que esta regla es coincidente con la prevista en la compraventa, por el incumplimiento del no pago del precio, sin perjuicio de tener presente que la doctrina nacional se inclina por reconocer en este pacto una condición resolutoria ordinaria ${ }^{41}$.

A partir de lo expuesto y de la ubicación del artículo 1486 del Código civil, previa a la regulación de los efectos de la condición resolutoria cumplida, entre las partes (artículos 1487 y 1488 el Código civil) y terceros (artículos 1490 y 1491 del Código civil); podemos colegir que el inciso segundo del artículo 1486 ha previsto consecuencias en la estructura de las obligaciones sujetas solo a condición suspensiva. Esta solución nos parece resulta difícil de aplicar en la estructura de la resolución fundada en el incumplimiento contractual, sin perjuicio de que el legislador proporcione reglas especiales en la compraventa y pacto de retroventa que descansan en la estructura propia de una condición resolutoria. Estimamos que verificado un incumplimiento grave y decretada la resolución pueden tener lugar obligaciones restitutorias, mas estas al no estar expresamente regladas las soluciones a los problemas restitutorios que puedan originarse, se rigen por la aplicación de principios generales, en particular, el enriquecimiento sin causa, como lo desarrollaremos más adelante y no necesariamente por la aplicación de estas normas.

\section{c. Pérdida de la cosa}

Si la cosa se ha perdido fortuitamente la doctrina nacional afirma no hay obligación, pero si es culpable, el deudor debe el precio y la indemnización de perjuicios. Los autores desprenden lo anterior del ya referido artículo 1486 inciso $1^{\circ} \mathrm{y}$, reiterando el tenor de la norma afirman, que si la pérdida de la cosa es fortuita la obligación se extingue, operando como modo de extinguir la obligación. Si se debe a culpa, el precepto indica expresamente que el deudor es obligado al precio y a la indemnización de la $\cos ^{42}$.

\footnotetext{
${ }^{41}$ AlesSandri (2003), p. 183.

42 Por todos, véase Aвецiuk (2010), p. 500.
} 
Por nuestra parte, como adelantáramos, nos parece que el tenor de la disposición acota su campo de aplicación a las condiciones suspensivas. Sin embargo, teniendo en consideración las reglas generales en la materia, artículos 1670 y 1672 del Código Civil, referidos a la pérdida de la cosa que se debe como modo de extinguir las obligaciones, es posible llegar a soluciones análogas en el caso de las condiciones resolutorias.

Precisamos sí que aun cuando se pueda arribar a la misma solución ${ }^{43}$, no nos resulta tan prístino que esta sea la que más se aviene a los supuestos de resolución por incumplimiento, si se tiene presente el principio fundamental en la materia: el enriquecimiento sin causa. No debe perderse de vista que el supuesto basal es que se ha producido un incumplimiento contractual de gravedad suficiente que permite dar lugar a la resolución. Decretada esta judicialmente y habiendo una o ambas partes dado cumplimiento con sus prestaciones es necesario proceder a las restituciones. Entendemos que en caso de pérdida de la cosa que debe ser restituida se configura una imposibilidad de restitución, quedando por definir si es o no procedente un equivalente pecuniario. Sin perjuicio de que puedan incluso traerse a colación las reglas de la teoría de los riesgos, cuando ambos contratantes han cumplido imperfectamente con sus obligaciones y estén obligados a restituir sus prestaciones, la de uno de ellos se ha hecho imposible por caso fortuito. Por esto, nos resulta necesario definir si el vínculo de reciprocidad e interdependencia propio de los contratos bilaterales tiene trascendencia una vez que se ha verificado el incumplimiento del mismo y si incide el efecto retroactivo que se le suele atribuir a la resolución por incumplimiento.

Nosotros creemos que en estos casos procede un equivalente pecuniario, fundado en la aplicación de los principios generales que gobiernan la materia. Si se predica un efecto retroactivo, el contrato propiamente tal nunca ha existido y deberá procederse a borrar todas sus consecuencias jurídicas y, en ese escenario, cobrará plena vigencia lo preceptuado en el artículo 1486 inciso $1^{\circ}$ del Código civil, que es coherente con lo prevenido en el artículo 1672 del mismo cuerpo legal. En cambio, como sostenemos, si no es una consecuencia de la esencia o necesaria de la resolución la retroactividad y se logra esta diferenciar de los efectos restitutorios que pueden originarse, existen mayores razones para otorgar a favor del contratante, a quien no se le podrá restituir la cosa porque se

${ }^{43}$ Así se desprende en Alcalde quien afirma "Cuando la restitución se torna imposible por la pérdida de la cosa, la obligación de restituir se perpetúa ya en una cosa el mismo género y condición, ya en su equivalente pecuniario (precio), considerado el nivel mínimo de satisfacción del interés del acreedor (artículos 621, 634, 662 III, 663 II, 910 II, 1486 I, 1502 II, 1504 II, 1521, 1532, 1533, 1534, 1672, 1675, 1678, 1743, 2084 III, 2086, 2178 II, 2198 y 2230 CC)". Alcalde, p. 20. 
ha perdido fortuitamente, un equivalente pecuniario porque el contrato como tal ha existido y existe y su estructura de reciprocidad se mantendría, justificándose en virtud del principio del enriquecimiento sin causa -al cual nos referiremos con mayor detención más adelante- dicho equivalente ${ }^{44}$.

Finalmente queremos consignar que esta solución no es ajena entre nosotros, es la que parece desprenderse de la regulación, por ejemplo, de los efectos de los vicios redhibitorios, artículos 1861 y 1862 del Código civil cuando ejercida la "acción rescisoria" -que la mayoría de la doctrina y jurisprudencia entiende es una acción resolutoria- no es posible la restitución de la cosa porque ha perecido por un defecto del vicio inherente a ella, se prevé una indemnización de perjuicios ${ }^{45}$.

\section{d. Los frutos de la cosa}

La regla que se indica en la materia es que los frutos producidos por la cosa pendiente la condición, son del deudor. Se menciona el artículo 1488 del Código civil que zanja la situación de los frutos tratándose de la condición resolutoria cumplida, aplicando una norma que no recoge el principio de la retroactividad de las condiciones y que es calificada por la doctrina como una regla práctica más que jurídica, en la que el legislador privilegia la estabilidad y evita devoluciones odiosas ${ }^{46}$. En efecto, la norma dispone: "Verificada la condición resolutoria, no se deberán los frutos percibidos en el tiempo intermedio, salvo que la ley, el testador, el donante o los contratantes, según los varios casos, hayan dispuesto lo contrario".

La solución enunciada no es la misma que el legislador adopta en materia de compraventa, ya que el artículo 1875 del Código civil prevé la restitución de los frutos en caso de resolución por incumplimiento del pago del precio,

${ }_{44}$ En el derecho español, Clemente comentando normas equivalentes a las nuestras exhibe todas las posibles alternativas de solución a los problemas de pérdida de la cosa que debe restituirse, considerando: si la cosa se pierde antes o no de que el contratante no incumplidor opte por la resolución, la aplicación del carácter retroactivo a la resolución, si se le reconoce a este remedio un carácter sancionatorio, el principio de reciprocidad. Se precisa sí que el autor concluye que es más adecuado a las características de la resolución por incumplimiento, al principio de reciprocidad en la restitución y al menor desplazamiento del riesgo, que ambos contratantes vengan obligados a restituir, ya en forma específica, ya por equivalente, en caso que la cosa que deba restituirse se pierda antes de que se optare por la resolución. Si es después, la solución es distinta, aplica las reglas de la pérdida de la cosa que se debe, el riesgo lo sufrirá el acreedor de la restitución. Confróntese. Clemente (1998), pp. 535-546. El principio del enriquecimiento sin causa se aborda infra 2.2.

45 Dízz (1998), p. 161. Alessandri (2003), pp. 135-136.

46 FueYo (1958), pp. 116 y ss. y p. 139. 
cuyo alcance varía dependiendo de si se paga o no todo o parte del precio ${ }^{47}$. La doctrina justifica esta norma en el carácter conmutativo que se le atribuye al contrato de compraventa, calificándose de justa y equitativa porque de lo contrario el comprador se aprovecharía de los frutos e intereses de todo o parte del precio que debe, con un perjuicio evidente para el vendedor que esperaba obtener utilidades con la suma impaga; darle todos los frutos e intereses conIlevaría a un enriquecimiento sin causa ${ }^{48}$. A propósito de esta regla, parte de los autores, han hecho extensiva la presunción de mala fe que prevé el inciso $3^{\circ}$ del artículo 1875, que entiende que para efectos de los abonos de expensas al comprador se le considera poseedor de mala fe, equiparan el incumplimiento que se presume culpable a la noción de mala fe ${ }^{49}$, y así el profesor Alessandri afirma que "el comprador debe restituir los frutos como un poseedor de mala fe, o sea, debe restituir los frutos naturales y civiles de la cosa, y no solamente los percibidos, sino los que el vendedor hubiere podido percibir con mediana inteligencia y actividad, si hubiera tenido la cosa en su poder. Estos frutos se deben desde que el comprador entró en posesión (artículo 907 del Código Civil)" ${ }^{\prime 50}$. A través de este reenvío se aplican nuevamente las reglas de la acción reivindicatoria.

Nos parece que la regulación en materia de compraventa, artículo 1875 del Código civil recoge las particularidades propias del incumplimiento de la obligación de pagar el precio en este contrato y que difícilmente puede entenderse que sea una regla general en la materia. Mantenemos nuestra crítica de aplicar en la materia reglas vinculadas a la buena o mala fe de las partes, que introduce un elemento que nos sitúa en planos jurídicos distintos. A nuestro juicio, la solución viene dada por aplicación, nuevamente, del principio del enriquecimiento sin causa y de la no retroactividad en materia de resolución,

47 El artículo 1875 del Código civil dispone: "La resolución de la venta por no haberse pagado el precio, dará derecho al vendedor para retener las arras, o exigirlas dobladas, y además para que se le restituyan los frutos, ya en su totalidad si ninguna parte del precio se le hubiere pagado, ya en la proporción que corresponda a la parte del precio que no hubiere sido pagada.

El comprador a su vez tendrá derecho para que se le restituya la parte que hubiere pagado del precio. Para el abono de las expensas al comprador, y de los deterioros al vendedor, se considerará al primero como poseedor de mala fe, a menos que pruebe haber sufrido en su fortuna, y sin culpa de su parte, menoscabos tan grandes que le hayan hecho imposible cumplir lo pactado".

${ }^{48}$ Vío (1945), p. 378.

${ }^{49}$ Vío (1945), p. 378. El autor reconoce que el legislador sólo lo establece expresamente para las expensas y deterioros, sin embargo, no ve razones para restringir la aplicación de esta regla, mas si el incumplimiento se presume culpable, el deudor debe estar de mala fe. En esta dirección Alessandri quien precisa que esta regla la tomó el legislador civil de Pothier. AlesSANDri (2003), p. 560.

${ }^{50}$ Vío (1945), pp. 560-561. 
por esto sostenemos que los frutos percibidos con anterioridad a que haya operado la resolución corresponderán al deudor de la obligación de restituir; con posterioridad, al acreedor de esta obligación.

\section{e. Reflexiones acerca de los efectos que la resolución produce entre las partes}

Luego de analizar los efectos de la resolución, con relación a las partes, podemos afirmar que la aplicación de las "reglas comunes en esta materia" no se condice con la naturaleza y fundamento de la facultad resolutoria, hay en esta materia un vacío o laguna legal. Se puede advertir que estas "reglas comunes", que en definitiva en doctrina se prevén tanto para la condición suspensiva como resolutoria, no siempre se avienen con la estructura de una condición resolutoria. Precisado esto, entendemos que tampoco sería posible aplicar analógicamente estas reglas a los supuestos de resolución por incumplimiento, toda vez que concebimos a esta facultad como un remedio sinalagmático que se verifica ante el incumplimiento grave o resolutorio; no estamos en presencia de una verdadera condición. Obsta para poder aplicar la analogía, como una forma de colmar el vacío o laguna legal, la igualdad jurídica esencial para poder extraer una regla, de las normas del cumplimiento de las condiciones, que sea aplicable a las restituciones a que puede dar lugar la resolución por incumplimiento. En efecto, uno de los requisitos para que opere la analogía es que entre el caso no regulado y el regulado "exista no una semejanza trivial, sino una semejanza relevante, es decir, es necesario sacar de los dos casos una cualidad común a ambos que sea al mismo tiempo la razón suficiente por la cual al caso no regulado se le atribuye aquella consecuencia y no otra" ${ }^{\prime 51}$. No concibiendo al incumplimiento como una genuina condición no contamos con algún elemento relevante que nos permita aplicar la solución que el legislador proporciona en materia de condiciones a la resolución por incumplimiento; hay claramente una naturaleza jurídica diferente entre ambas instituciones.

Muchas de las normas analizadas precedentemente, además, descansan en la lógica de la retroactividad que se predica de las condiciones. No desconocemos que la resolución pueda dar lugar a obligaciones restitutorias mas no identificamos esta obligación con un efecto retroactivo. Veremos, más adelante, que incluso aquella doctrina que afirma el carácter retroactivo de la resolución reconoce una serie de excepciones que ponen en tela de juicio que efectivamente pueda tenerse al contrato como no celebrado ${ }^{52}$. Tampoco debe perderse

51 Squella (2014), p. 676. En similar dirección, Cerdeira (2012), p. 1041.

${ }^{52}$ Véase infra 2.1. 
de vista que el carácter retroactivo, aun en el caso de las condiciones, ha sido discutido, sobre ello volveremos más adelante ${ }^{53}$.

Las reglas previstas en materia de compraventa, a nuestro juicio, tampoco nos sirven para ser aplicadas analógicamente y dar solución a la laguna legal que se nos presenta. No es posible extraer de esta normativa, un principio general. Ciertamente estas reglas están previstas en casos de incumplimiento contractual y de resolución, mas como hemos dejado consignado, se trata de reglas especiales que se hacen cargo de dar solución a las particularidades que se presentan cuando la obligación incumplida es la de pagar el precio, de manera que no creemos que puedan ser generalizadas para cualquier incumplimiento contractual, incluso en el contrato de compraventa ante el incumplimiento de una obligación distinta de la de pagar el precio.

Por lo expuesto, precedentemente, entendemos que ninguna de las normas analizadas proporciona una solución adecuada. Postulamos que para colmar este vacío o laguna legal será menester acudir a los principios generales del derecho y en concreto, al principio del enriquecimiento sin causa para fundar en él la obligación restitutoria ${ }^{54}$. También volveremos sobre esto más adelante ${ }^{55}$.

\subsection{Efectos de la resolución con relación a los terceros}

Tratándose de los terceros, la doctrina pone de manifiesto que nuestro legislador no ha mantenido el rigor de la retroactividad de la resolución, ya que conforme a ella los actos de disposición deberían quedar sin efecto: resuelto el derecho del causante se resuelve también el derecho del causahabiente; mas esto no es asi ${ }^{56}$. El Código civil permite privar de efecto sólo a aquellas enajenaciones en las que el adquirente sabía o debía saber el derecho resoluble de su causante; vincula la adquisición a la buena fe subjetiva para determinar si esta se consolida o sanea, a partir de lo dispuesto por sus artículos 1490 y $1491^{57}$.

\footnotetext{
${ }_{53}$ Véase infra 2.1.

${ }^{54}$ Es clara la discusión que ha existido en torno al concepto de principios generales del derecho, su número y función. Sobre el particular, véase DeL VECCHIO (1971), pp. 41 y ss. Entre nosotros, es usualmente aceptada su rol como integrador de vacíos o lagunas legales y, dentro del catálogo de los mismos, se incorpora al principio del enriquecimiento sin causa, PeÑAiliLlo (2012), pp. 7 y ss.

55 Véase infra 2.1 y 2.2.

${ }^{56}$ Aвеціuk (2010), p. 539. El autor incluso afirma que en esta materia el legislador perdió la excelente redacción que lo caracteriza.

${ }^{57}$ Consignamos que la doctrina nacional ha discutido si estas disposiciones se aplican sólo a la condición resolutoria o también a la condición suspensiva y al plazo. Se critica, además, la redacción que emplea el legislador porque del contrato no nacen derechos reales y es el derecho real de dominio que se puede detentar lo que justifica que el legislador otorgue acción reivindicatoria. Por todos,
} 
Destaca que en esta materia el legislador emplea las mismas reglas, los artículos 1876 del Código civil -resolución de la compraventa por no pago del precio-y 1882 del Código civil -en el pacto de retroventa- se remiten expresamente a lo previsto por los artículos 1490 y 1491 del Código civil. De esta forma los supuestos de condición resolutoria y de resolución por incumplimiento se gobiernan, en principio, por las mismas reglas.

Centrándonos en el análisis de estas disposiciones, el artículo 1490 del Código civil se refiere a la enajenación relativa a un cosa mueble y establece que "[s] i el que debe una cosa mueble a plazo, o bajo condición suspensiva o resolutoria, la enajena, no habrá derecho de reivindicarla contra terceros poseedores de buena $\mathrm{fe}^{\prime \prime}$ y si es un bien inmueble, el artículo 1491 del Código civil prescribe: "Si el que debe un inmueble bajo condición lo enajena, o lo grava con hipoteca, censo o servidumbre, no podrá resolverse la enajenación o gravamen, sino cuando la condición constaba en el título respectivo, inscrito u otorgado por escritura pública".

En estas hipótesis el legislador, como consecuencia de la resolución, permite ejercer acción reivindicatoria, siempre que el tercero adquirente no esté amparado por la buena fe. La doctrina ha entendido que es una situación típica de protección de la apariencia jurídica; "conforme a ella, los terceros que se guían por lo que observan, por lo que aparece como real, estando de buena fe, deben ser protegidos por el derecho" ${ }^{\prime \prime 5}$. Ciertamente estaremos ante una colisión de intereses entre la seguridad del tráfico -seguridad dinámica- y la seguridad de la riqueza ya adquirida -seguridad estática- que se resuelve a favor de la primera en aquellos casos en que el tercero actúa de buena fe, a partir de una creencia errónea, por medio de un título oneroso ${ }^{59}$.

En el primer caso, la buena fe exige que éste logre la convicción de haber adquirido la cosa legítimamente, lo que presupone -afirman los autores- que haya realizado aquellas indagaciones que denoten una diligencia media ${ }^{60}$;

véase Aвelıuk (2010), pp. 540 y ss.; Vío (1945), pp. 386-387. Nosotros nos hemos centrado sólo en la condición resolutoria, razón por la que esta discusión no resulta trascendental.

58 Peñallillo (2012), p. 48.

59 Peñallillo (1999), pp. 12-15, 24-28 y 29-30. El mismo autor, en su tratado de obligaciones, agrega como requisito para que no prospera la acción reivindicatoria contra terceros adquirentes, de conformidad a los artículos 1490 y 1491, que hayan adquirido a título oneroso. Confróntese PeÑalitlo (2003), p. 454.

${ }^{60}$ En esta dirección FuEYo (1958), p. 141. El autor menciona como ejemplos, las averiguaciones sobre el anterior dueño, el título de adquisición actual, la comprobación de estar pagado el precio, etc. Igualmente, Peñailillo alude a una actuación correcta, lícita que se califica con base en el comportamiento objetivo del tercero, se considera una conducta diligente atendidas las circunstancias -comportamiento socialmente exigible-. No obstante, precisa que en esta materia lo realmente relevante es que el tercero 
de toda forma, como pone de manifiesto parte de la doctrina, la buena fe se presume, de manera que quien alega lo contrario es quien deberá probarlo ${ }^{61}$. En el segundo caso, la buena fe, va a depender si en el título constaba o no la condición ${ }^{62}$.

Tratándose de los bienes inmuebles en doctrina se ha discutido cuándo se entiende constar la condición, es decir, si sólo pueden contar en el título inscrito u otorgado por escritura pública en las condiciones expresas -condición resolutoria ordinaria y pacto comisorio- o también las tácitas. Al respecto, el profesor Abeliuk afirma que a estas alturas el problema debe considerarse totalmente resuelto, se incluirían ambas, e indica que las razones más importantes son: 1) El significado de la expresión "constar" de acuerdo al Diccionario de la Lengua evoca certeza y la condición resolutoria, al estar establecida en el artículo 1489 del Código civil tiene claramente este carácter. 2) El artículo 1876 se refiere a la condición resolutoria tácita en la compraventa y se remite expresamente a los artículos 1490 y 1491 para determinar cuándo la resolución por el no pago del precio da derecho contra terceros poseedores. 3) La diferente redacción con el artículo 1432 referido a la resolución de las donaciones que exige que la condición debe expresarse, lo que no se requeriría acá63.

Si seguimos esta interpretación tendríamos que colegir que ejerciéndose la facultad resolutoria, prevista en el artículo 1489 del Código civil, los terceros adquirente siempre estarían de mala fe, ya que existiría la certeza de la existencia de la condición al estar prevista esta facultad en la ley, argumento que se aplicaría con independencia de si la cosa es mueble o inmueble ${ }^{64}$. Esta interpretación, comprende a los terceros que si bien no sabían estaban en condiciones de saberlo, es decir, que actuaron de manera poco diligente. Se equipara un

ignorara que el derecho era resoluble, aunque haya podido ser negligente. De esta forma se entenderá que está de mala fe, si sabe que el derecho era resoluble o se equipara a éste, si sabía y asumió el riesgo. PeÑallillo (2003), pp. 455-457.

${ }^{61}$ Vío (1945), pp. 387-388.

62 Fueyo (1958), pp. 143-144.

${ }^{63}$ Abeluuk (2010), pp. 545-544. En esta misma dirección, Claro (1978), pp. 144-146. Menciona otras razones Vío (1945), pp. 385 y ss., quien adiciona: a) Que la situación es fácil de advertirse por el tercero al analizar el título primitivo, si ha quedado alguna obligación sin cumplirse. b) La ubicación de la disposición, luego del artículo 1489. c) El artículo 2416 que reafirma esta interpretación. d) la historia del artículo 1491 da cuenta de la intención del legislador de incorporar a la condición resolutoria tácita en especial en el proyecto de 1853. e) Finalmente consigna la opinión unánime de tratadistas y profesores.

${ }^{64}$ La doctrina de forma previa a analizar este problema, al menos, tratándose de las cosas muebles afirma que el poseedor actual de la cosa no requiere probar la buena fe, esta prueba corresponde al acreedor condicional, él deberá probar la mala fe, es decir, que actuó a sabiendas de que la persona de quien adquiría la cosa lo hacía bajo condición. Confróntese Claro (1978), pp. 141-142. 
actuar culpable con la mala fe ${ }^{65}$, cuestión que no compartimos porque como ya precisamos se trata de nociones diferentes que tienen dentro de nuestro Código civil orientaciones diversas.

Nos parece que es necesario revisar esta regla porque así entendida afecta el tráfico jurídico y una de las razones que implica a la protección de los terceros, a través de la teoría de la apariencia jurídica, ya que se reconocería que siempre es posible ejercer acción reivindicatoria en contra de ellos. Incluso, puede sostenerse que implicaría una suerte de presunción de mala fe, debiendo los terceros si quieren verse amparados por lo dispuesto en los artículos 1490 y 1491 del Código civil probar su buena fe, sin perjuicio de que, sobre la base de lo afirmado por parte de la doctrina, pueda discutirse esta posibilidad por estimarse que en estas materias estaríamos ante una presunción de derecho ${ }^{66}$. Se contraría de esta forma, por la interpretación que se le da a esta norma, la presunción general de buena fe, que nuestra doctrina y jurisprudencia desprenden del artículo 707 del Código civil ${ }^{67}$. Nos parece más adecuado entender que la mala fe debe ser probada y este es solo uno de los posibles antecedentes a considerar, situación que no deja en una posición desmejorada al contratante a quien debe restituirse porque siempre podrá dirigirse en contra de su otrora co-contratante por una restitución en equivalente, ante la imposibilidad de que en naturaleza se produzca. Se concilian así los intereses de las partes concernidas en la resolución, los de aquellos terceros que actúan de buena fe y la seguridad del tráfico jurídico. En la misma dirección estimamos se encuentra el profesor Díez-Picazo, quien analizando los efectos de la resolución respecto de terceros, a partir del párrafo final del artículo 1124 del Código civil español que supedita los efectos restitutorios de cara a terceros adquirentes a que estén de mala fe y sobre el particular sostiene: "Por mala fe no debe entenderse la simple conciencia o conocimiento en el momento de llevar a cabo la adquisición de que el transmitente o disponente tenía un contrato pendiente de cumplimiento. Debe, por ello, considerarse como mala fe el conocimiento, en el momento de adquirir, de que el susodicho contrato se encontraba ya incumplido" ${ }^{\prime 68}$.

\footnotetext{
65 Peñallillo (2003), pp. 461-462.

${ }^{66}$ Confróntese Peñallillo (2003), pp. 461 y ss.

67 Por todos, PeÑallillo (2010), pp. 357-358.

${ }^{68}$ Dí́z-PICAZO (2008), p. 874. En similar dirección, haciéndose presente que hay norma expresa en la ley hipotecaria que avala esto, Clemente afirma que la mala fe del tercero adquirente no se refiere únicamente al conocimiento o conciencia de que el contrato se encuentra pendiente de cumplimiento sino también al conocimiento o conciencia de que el contrato ha sido incumplido; sin perjuicio de considerarlo, además de mala fe, si el tercero tenía conocimiento o conciencia de que el contrato había sido resuelto por incumplimiento. Confróntese Clemente (1998), pp. 551-552.
} 
No debe perderse de vista tampoco, como lo apunta el profesor Peñailillo, que el texto del artículo 1491 exige que el título en que la condición conste esté "inscrito u otorgado por escritura pública" y siendo nuestro sistema registral de inscripciones y no de transcripciones, puede acontecer que, constando la condición en el título, la inscripción no dé cuenta de ella. Consignamos sí que el autor concluye que basta con que se mencione en el título ya que un grado normal de diligencia exige que, tratándose de inmuebles, el tercero examine el título y la inscripción. De esta forma siempre está en condiciones de saber de la existencia de la condición ${ }^{69}$. En el mismo sentido se han pronunciado nuestros tribunales, así la Excma. Corte Suprema lo ha establecido al decidir: "No es exacto que, para la validez de una condición resolutoria contra terceros, sea necesaria la inscripción de la misma condición, bastando para los propósitos que persigue la ley, la simple inscripción del título respectivo o el otorgamiento por escritura pública del contrato que contiene la condición resolutoria. Esta doctrina está consagrada sin la menor duda en el artículo 1491 (del Código Civil)"170.

En nuestros tribunales podemos advertir distintas argumentaciones con relación a la buena o mala fe de los terceros adquirentes. Así en ciertas ocasiones exige claramente la prueba de la mala fe, no obstante discutirse si la condición constaba en el título por consignarse en él la modalidad que afectaba el pago, por ejemplo: tratándose del contrato de compraventa, donde va implícita la facultad resolutoria, se ha negado la procedencia de la acción reivindicatoria contra terceros, no obstante declararse resuelto el contrato, porque no se ha probado la mala fe de estos. Los jueces del fondo consideraron que "la demandante cumplió con su obligación de vender, ceder y transferir los bienes y derechos de que se trata y que la demandada Standar Gold S.A., incurrió en el incumplimiento contractual invocado, al no pagar los saldos de precios adeudados, resolvieron acoger la acción resolutoria ejercida. Respecto de la reivindicación resuelven su rechazo, en atención a lo dispuesto por los artículos 1876 y 1491 del Código Civil, al estimar que para que el actor pueda reivindicar contra la demandada Callsir International S.A. debió probar que ésta había perdido la buena fe, la que conforme a la ley se presume, lo que no aconteció en la especie"71.

${ }^{69}$ Confróntese Peñallillo (2003), p. 466.

${ }^{70}$ Considerando vigésimo primero Corte de Apelaciones de Santiago, Rol № 6324-1988, de 21 de junio de 1991.

${ }^{71}$ Corte Suprema, Rol № 2679-2010, de 13 de septiembre de 2010, c. $3^{\circ}$. Conforme a los hechos probados, el 30 de mayo de 2001 el demandante y la demandada, Estándar Gold S.A., celebraron contratos de compraventa de acciones y cesión de derechos de manifestación minera y con fecha 21 de noviembre de 2003 la compradora vendió a su vez a Callsir International S.A. las cincuenta accio- 
En otras ocasiones, en similar hipótesis, entiende que la condición constaba en el título por el hecho de consignarse en él que el saldo del precio debía ser pagado en cuotas, así por ejemplo, la Excma. Corte Suprema ha resuelto: "Que, de acuerdo a los hechos que los sentenciadores han dejado asentados en la litis, ya pormenorizados en la segunda consideración y, dado que un saldo del precio de la compraventa de acciones suscrita entre el demandante y la demandada señora Zúñiga en el mes de abril de 2004, debía ser enterado en cuotas mensuales, conforme se lee en la tercera cláusula del instrumento que corre a fojas 1, cuyo incumplimiento, en definitiva, redundó en la declaración judicial de la resolución de dicho contrato, en causa Rol No 492-2005, aparece nítido que las convenciones de 8 de junio de 2004 y de 12 de julio de 2006(sic), a las que toca el pleito, se ven alcanzadas por el efecto resolutorio reflejo pues, atendidos los términos en que adquirió la demandada señora Zúñiga, ninguno de ellos puede alegar desconocimiento acerca de la existencia de la condición resolutoria pendiente envuelta en el contrato de compraventa celebrado el 15 de abril de 2004. Surge, entonces, para el demandado señor Ringele -en su carácter de tercer adquirente en virtud del contrato celebrado con fecha 12 de julio de 2006 (sic)-, la extinción de su derecho de propiedad de las acciones adquiridas y el deber de restituirlas pues, como se viene diciendo, del tenor en que se pactó la obligación de pagar el precio por las acciones adquiridas su causante, queda de manifiesto que no pudo menos que saber que pendía la condición resolutoria correspondiente" ${ }^{\prime 72}$. En la misma dirección la Corte de Apelaciones de Santiago ha sostenido "Que atendido que en el título del

nes y los derechos de manifestación sobre las mineras, referidas en el primer contrato. El demandante cumplió con su obligación de vender, ceder y transferir las acciones y ceder los derechos de manifestación minera; la demandada Standard Gold S.A. no pagó al actor los saldos de precio adeudados. Callsir Internacional S.A., era el poseedor inscrito de los bienes objeto de los contratos materia de autos y no se probó su mala fe.

72 Corte Suprema, Rol № 4396-2009, de 6 de diciembre de 2010, c. $13^{\circ}$. Conforme a los hechos probados, el demandante y demandado por escritura pública otorgada con fecha 16 de septiembre de 2002, debidamente inscrita en el Registro de Comercio, constituyeron la sociedad Escuela Básica Javiera Carrera Limitada.

El 15 de abril de 2004 el demandante vendió, cedió y transfirió el total de los derechos y acciones que poseía en la sociedad a la demandada doña Rosa Zúñiga, quien los compró y adquirió para sí en la suma total de $\$ 70.000 .000$. Este contrato fue declarado resuelto por sentencia definitiva de 10 de abril de 2006, confirmada por sentencia de segunda instancia de 18 de octubre de 2006, encontrándose firme y ejecutoriada, subinscrita el día 11 de enero de 2007 al margen de la matriz de la escritura del contrato declarado resuelto y de su inscripción conservatoria.

El 8 de junio de 2004, el demandado señor Tomás González tomó conocimiento, ratificó e hizo suyo en todas sus partes el contrato de compraventa de derechos y acciones suscrito entre el actor y la demandada señora Zúñiga el día 15 de abril de 2004, aceptando a la nueva socia y modificando la sociedad en lo pertinente, debidamente inscrita. 
demandado de resolución que sirvió de antecedente a la adjudicación del inmueble por parte de la demandada de reivindicación hay constancia del saldo de precio, esto es en la escritura pública que en copia corre a fs. 129, debe procederse en contra de ésta porque ello importa que lo adquirió conociendo la existencia de la cláusula resolutoria, lo que implica mala fe"73.

A nuestro juicio, los inconvenientes que plantea la aplicación de los artículos 1490 y 1491 del Código civil van ligados a entender a la facultad resolutoria como una condición implícita, esto necesariamente lleva a comprender que el tercero adquirente sabía o, al menos, debía saber que el derecho era resoluble. A nuestro parecer la regla y el principio que se extrae de estas disposiciones, teniendo en consideración, además, la teoría de la apariencia jurídica, es que los terceros que han contratado de buena fe a título oneroso, sea que la cosa adquirida por tradición sea mueble o inmueble, no se verán obligados a restituir; de esta forma el deudor de la obligación de restitución tendrá que dar un equivalente pecuniario al acreedor. Para todos estos efectos entendemos que la buena fe se presume. Ahora bien, como la resolución por incumplimiento no lo abordamos como una causal de ineficacia jurídica, la respuesta más acorde se vincula con la protección de la apariencia jurídica y no con la resolución del derecho del constituyente que, a su vez, da lugar a la acción reivindicatoria; terreno donde se sitúa la discusión en torno a la eficacia real o personal de la resolución ${ }^{74}$.

\section{Los efectos de la resolución por incumplimiento, en especial, del efecto restitutorio.}

En este apartado precisaremos si los efectos restitutorios se identifican con la retroactividad que se predica de la resolución por incumplimiento, aclarando previamente si ésta es realmente un efecto necesario de ella. Luego ahondaremos en las tradicionales excepciones que la doctrina menciona al efecto retroactivo. Asumiendo que la resolución puede dar lugar a obligaciones restitutorias proporcionaremos aquellas reglas por las cuales ésta debería ser gobernada.

El 2 de julio de 2006, la demandada señora Zúñiga vendió y transfirió el total de los derechos y acciones de los que era dueña en la sociedad a don Luis Ringele, lo que fue aceptado por el socio González, quedando como únicos socios los señores González y Ringele.

Misma argumentación, aunque sin ahondar en ello se advierte en Corte Suprema, Rol № 3103-2012, de 14 de marzo de 2012.

${ }^{73}$ Corte de Apelaciones de Santiago, de 31 de enero de 2002, c. $3^{\circ}$.

${ }^{74}$ La eficacia es real si la resolución determina la readquisición del derecho real con retransmisión automática y personal si como consecuencia de la resolución las partes quedan obligadas recíprocamente a la situación existente antes de contratar. 
Finalizaremos este apartado exponiendo la regulación que el nuevo derecho de la contratación brinda a los efectos de la resolución.

\subsection{Una cuestión previa: ¿la retroactividad es un efecto necesario e indispen- sable?}

Tal como hemos adelantado, si bien tradicionalmente se afirma que la resolución del contrato opera con efectos retroactivos -debiendo dejarse a las partes en la situación previa a la celebración del contrato-, es cierto que en doctrina se ha cuestionado este efecto en materia de condiciones y, con mayor razón, tratándose de la facultad resolutoria. Tampoco debe perderse de vista que el tenor de las disposiciones concernidas dejan claro que el legislador nacional ha construido la retroactividad de la resolución centrándose en las obligación de dar y, en rigor, de dar una especie o cuerpo cierto; y esto ha llevado a la doctrina a cuestionar el carácter retroactivo en las obligaciones de hacer ${ }^{75}$.

En materia de condiciones, la doctrina ha puesto de relieve la dificultad de fundamentarlo en términos puramente racionales. Sin embargo, surgen tradicionalmente razones históricas, en concreto, su origen romano ${ }^{76}$ y el carácter de ficción legal que justificaría este efecto retroactivo ${ }^{77}$; ambos aspectos que pueden ser cuestionados.

En el derecho romano cabe precisar, por una parte, que la condición resolutoria no se extingue ipso iure al cumplirse y, por otra, que ella no existe como categoría autónoma y distinta de la condición suspensiva ${ }^{78}$. En la materia rige el principio que no puede deberse durante un cierto tiempo y que una obligación se extingue sólo en virtud de un modo civil y típico, la cesación es por derecho pretorio mediante una exceptio pacti o exceptio doli ${ }^{79}$. En lo que respecta al efecto retroactivo, en las condiciones suspensivas, cumplida ésta, la obligación se considera nacida desde el momento en que fue celebrada la estipulación -“ex tunc"-, esto se debe al carácter formal de la estipulación ${ }^{80}$. Es por esto,

\footnotetext{
75 Hinostrosa (2008), p. 479. El autor señala que la tendencia actual es contraria a la retroactividad, teniendo en cuenta la economía del contrato y el interés de las partes, "comenzando por su negación en (sic) tratándose de obligaciones de hacer y, sobresalientemente, de contratos sucesivos y aun de ejecución escalonada".

${ }^{76}$ Confróntese Claro (1978), p. 130.

77 Confróntese Serinet (2001), pp. 590-591.

78 Confróntese Guzmán (2013), pp. 23-24.

79 Confróntese Guzmán (2013), pp. 23-24.

${ }^{80}$ GuZMán (2013), p. 32.
} 
que Guzmán afirma que no es posible colocar en un mismo nivel los efectos de la condición en una estipulación que en un contrato consensual, es "erróneo plantear el problema en términos de "efecto retroactivo": no se trata de si el cumplimiento de la condición produce o no tal efecto, que ciertamente no lo produce, sino de determinar en qué momento surge el negocio mismo, que es el único al que puede imputarse el efecto obligacional. Como la solución varía según el tipo de negocio, de ahí la disparidad de soluciones que ofrecen las fuentes, y la inexistencia de un principio general sobre la materia". Por su parte, Lazo luego de analizar un mismo caso -perecimiento de la cosa objeto de una estipulación condicional- en la jurisprudencia republicana y clásica, concluye que a los efectos que dicho perecimiento provocaba no se le asignó, por la jurisprudencia, efecto retroactivo al cumplimiento de la condición ${ }^{81}$.

Como indicáramos algunos justifican la retroactividad de las condiciones en la figura de la ficción legal, sería la ley la que ficticiamente, una vez cumplida la condición, atribuye los mismos efectos que se habrían producido si el acto hubiese surgido como puro y simple al momento de celebrarse el acto constitutivo. Detrás de esto, para algunos, está la función que desempeñaría la condición al venir a descubrir la verdadera naturaleza que la relación jurídica tenía; la fase intermedia es una forma de articular una situación que aún se desconoce. En este escenario se postula que se está simplemente ante una forma de reglamentar los intereses empleándose el criterio más útil para resolver los conflictos entre las partes, mas no es una regla que no pueda ser sustituida por la voluntad de las partes ni que no pueda ser flexibilizada en su aplicación ${ }^{82}$.

Si nos situamos ahora en la resolución por incumplimiento y ella no se considera como causal de ineficacia sobrevenida de la relación contractual sino un mecanismo más de defensa del acreedor lesionado por el incumplimiento, la retroactividad no surge como necesaria. Así el profesor Díez-Picazo, luego de descartar que se trate de una ineficacia contractual sobrevenida, se hace cargo de la aplicación de las reglas de las condiciones en la materia, por la inclusión que el Código civil español hace, al igual que el nuestro, de la facultad resolutoria en estas obligaciones, y afirma: "no debe olvidarse que el sistema de retroactividad de los efectos de la obligación condicional del art. 1120 debe considerarse específicamente ligado a las condiciones suspensivas, de manera que es muy difícil encajarlo en el supuesto de la resolución" ${ }^{\prime \prime 3}$, reconoce el autor que allí hay reglas especiales que si bien remiten a las obligaciones sujetas a condición suspensiva

81 Confróntese, Lazo (2006).

82 Díez-Picazo (2008), p. 418.

83 Díez-Picazo (2008), p. 873. Con una opinión contraria, analizando los distintos argumentos a favor de la retroactividad, Álvarez (1986), pp. 238 y ss., el autor concluye que se justifica tanto como sanción al 
para efectos de pérdida, deterioro o mejoras no prevén la retroactividad ${ }^{84}$. El autor considera que, en términos generales, la regla de la retroactividad de los efectos resolutorios puede aplicarse en las relaciones obligatorias de cambios con efectos instantáneos mas no cuando afecta a relaciones duraderas" ${ }^{\prime \prime 5}$.

Además no debe perderse de vista que existe consenso, en parte de la doctrina comparada y nacional, en que el contrato como tal no desaparece, no deja de existir y, por esto, se mencionan como excepciones del efecto retroactivo los contratos de tracto sucesivo y la cláusula penal; más recientemente se han agregado las hipótesis en que ninguna de las partes cumple y la obligación de hacer que es parcialmente ejecutada; sin perjuicio de todas aquellas cláusulas que producirían efecto una vez que se ha verificado el incumplimiento del contrato, presupuesto de la resolución, tales como: cláusulas de confidencialidad, cláusulas compromisorias, ni aquellas que reglan derechos y obligaciones entre las partes tras la resolución ${ }^{86}$. A los principales casos nos referiremos a continuación.

\section{a. Los contratos de tracto sucesivo}

Esta clase de contratos se caracterizan porque las obligaciones de las partes se van extinguiendo y renovando periódicamente, de allí que la doctrina y jurisprudencia nacional se inclinan por sostener que la resolución no produce efectos retroactivos, sino solo para el futuro. Por esto sería más preciso hablar de terminación del contrato ${ }^{87}$.

En la doctrina comparada se postula en estos casos una resolución parcial porque se originan una serie de prestaciones y atribuciones que si bien están en conexión pueden ser económica y jurídicamente diferenciadas. Los pares de prestaciones pueden separarse sin que se perjudique la finalidad del contrato; la resolución no afecta las prestaciones ya ejecutadas por ambas partes que tendrían el carácter de independiente sino solo a las futuras y las que solo una de las partes ejecutón ${ }^{88}$.

deudor por el incumplimiento como por tratarse del medio más adecuado para proteger los derechos e intereses del acreedor que ha cumplido.

${ }^{84}$ Díez-Picazo (2008), pp. 872-873.

85 Dí́z-Picazo (2008), p. 875.

${ }^{86}$ Fenor (2013), pp. 1612-1617. Respecto del Common Law, en la misma dirección, Treitel (2004), pp. 343-345; WhitTaker (2001), p. 992; Palazón (2009), pp. 807-808; Clemente (1998), pp. 507 y ss. Más adelante veremos como esto también se refleja en el nuevo derecho de la contratación.

${ }^{87}$ Véase por todos Alessandri (2009), p. 42. Y Abeliuk (2010), p. 513. En la misma dirección Corte Suprema, Rol № 7973-2013, de 9 de septiembre de 2013.

${ }^{88}$ Confróntese Clemente (1998), pp. 503-504. 
Nos parece que la limitación a la retroactividad se funda, desde la perspectiva que lo analiza la doctrina tradicional, en la propia naturaleza de este contrato. Las prestaciones ya ejecutadas fueron cumplidas operando el pago como modo de extinguir las obligaciones (ex artículos 1567 y 1568 del Código civil), no se produce ningún desequilibrio patrimonial que sea necesario corregir. Nos interesa sí destacar, del clásico ejemplo que la doctrina nacional emplea en la materia: el contrato de arrendamiento, implícitamente se reconoce que la retroactividad, en más de una ocasión no se justifica o es derechamente imposible ${ }^{89}$. Así entendemos, se refleja por el profesor Abeliuk quien señala "en un arrendamiento a dos años plazo, si el arrendatario paga la renta de los primeros 6 meses, pero deja entonces de cumplirlas, el contrato puede darse por terminado, pero el arrendador no deberá restituir las rentas percibidas, porque mal podría a su vez el arrendador devolver el uso y goce de la cosa arrendada" ${ }^{\prime 90}$.

\section{b. La cláusula penal}

Conforme a la regulación que nuestro Código civil proporciona a la cláusula penal (artículos 1535 y siguientes) se concluye que ella puede cumplir distintos roles: avaluación anticipada de los perjuicios, una caución personal y una pena. En esta materia lo que nos interesa es determinar cuál es la suerte de la cláusula penal pactada en caso de incumplimiento del contrato cuando se demanda su resolución fundado en el artículo 1489 del Código civil.

Tradicionalmente, como anticipamos, se plantea por la doctrina que la cláusula penal debe hacer excepción al efecto retroactivo del contrato porque su causa descansa en el incumplimiento del contrato y no en el contrato mismo que ha quedado sin efecto; a lo que por cierto se suman consideraciones prácticas -la poca utilidad de las cláusulas previstas precisamente en caso de incumplimiento si se les restara eficacia una vez que éste se ha verificado- ${ }^{91}$. En este sentido el profesor Corral afirma que "la resolución no es la nulidad del contrato, a la cual sí el Código sanciona con la ineficacia de la cláusula penal (art. 1536 CC). La resolución es consecuencia de un incumplimiento de una obligación válidamente contraída. En consecuencia, se produce con ella

${ }^{89}$ En esta dirección Clemente afirma que en estos casos la regla de la retroactividad carece de sentido económico o da lugar a resultados injustos. Clemente (1998), pp. 503-504.

${ }^{90}$ AвеLiuk (2010), p. 513.

${ }^{91}$ Sin perjuicio de que la razón de fondo para limitar la retroactividad admite distingos como da cuenta el profesor Corral (2012), pp. 257-258. Con una opinión contraria, que se considera minoritaria, Gatica Pacheco niega su procedencia fundado en el carácter retroactivo de la resolución y el carácter accesorio de la cláusula penal. Gatica (1959), pp. 430-431. 
el mismo supuesto en el que descansa la eficacia de la pena convencional: el incumplimiento ${ }^{\prime 92}$, en el mismo sentido se han pronunciado nuestros tribuna$\mathrm{les}^{93}$. Sí cabe consignar que entendemos que nada obsta que en el caso concreto proceda la cláusula penal y no la resolución porque el incumplimiento no tiene la entidad suficiente para ser calificado de resolutorio ${ }^{94}$.

Para determinar la posible compatibilidad de la cláusula penal con la resolución nos parece más adecuado, distinguir cuál es el rol en que ha sido pactada, de forma similar a lo que plantea el profesor Corral ${ }^{95}$, aunque no compartimos íntegramente ni sus distingos ni conclusiones.

En efecto, si las partes nada han precisado debe entenderse, a partir de lo dispuesto en los artículos 1537 y 1543 del Código civil que la pena está avaluando todos los perjuicios que sean una consecuencia del incumplimiento del contrato, lo que incluye el equivalente de la prestación y todos aquellos otros que sean una consecuencia directa e inmediata del incumplimiento mismo. Si el acreedor considera que los perjuicios reales exceden de aquellos que anticipadamente avaluó con su deudor, nada obsta a que prescinda de esta cláusula y persiga su reparación por la vía ordinaria, como claramente lo dispone el artículo 1543 del Código civil.

Entendida la cláusula penal de la forma expuesta y si se demanda la resolución del contrato, especial atención habrá que tener en determinar, para evitar que se produzca un enriquecimiento sin causa, si entre las partes se han generado obligaciones restitutorias. Si debe procederse a la restitución de la prestación ya ejecutada, nos parece más conforme al principio del enriquecimiento sin causa y a la regulación de la cláusula penal, que inspirada en él consagra expresamente el principio de la no acumulación entre la pena y la prestación

92 Corral (2012), p. 259.

93 Así se advierte en el considerando quinto de la sentencia de la Corte Suprema que consigna: "en lo referido al segundo apartado del libelo, que cuestiona la aplicación de la cláusula penal contenida en el contrato, esta Corte estima que tal aspecto ha sido correctamente resuelto por los jueces del fondo, al señalar acertadamente que en la especie no se trata de la nulidad del contrato, sino de su resolución como consecuencia del incumplimiento de obligaciones válidamente contraídas, por lo que existe plena complementariedad entre la resolución dispuesta y la multa solicitada y ordenada pagar, al descansar ambas sobre la misma hipótesis que ha sido debidamente acreditada, la infracción de los deberes emanados del contrato por parte de la promitente vendedora". Corte Suprema, Rol $\mathrm{N}^{\mathrm{o}}$ 7158-2014, de 10 de junio de 2014.

94 En el mismo sentido, Corral (2012), pp. 257-258.

95 En la materia el profesor Corral distingue: a) La pena compensatoria sustitutiva, aquella que persigue asegurar el valor de la prestación incumplida. b) la pena compensatoria indemnizatoria, aquella que pretende resarcir los perjuicios consecuenciales al incumplimiento y que son mayores al valor de la prestación. c) La pena moratoria, aquella que es pactada por el simple retardo. D) La pena puramente punitiva, aquella que es pactada en carácter de pena para el caso de incumplimiento. CORRAL (2012), pp. $253-254$. 
principal ${ }^{96}$, que debe descontarse del monto de la avaluación anticipada de los perjuicios aquella que equivale al valor de la prestación; de lo contrario se produciría una acumulación de indemnizaciones ${ }^{97}$. Una interpretación contraria no resulta sistemática al tenor del Código civil. Esta solución tampoco deja en una situación desmejorada al acreedor quien, como ya precisamos, siempre puede probar y demandar los perjuicios que realmente ha sufrido.

Si las partes expresamente han pactado la cláusula penal con carácter moratorio, es decir, anticipándose a los perjuicios que el retardo en el cumplimiento pudiese producir, no vemos objeción a priori de su compatibilidad con la resolución del contrato. Discrepamos, de esta forma, con la doctrina que plantea que esta clase de cláusula penal sólo es compatible con la ejecución forzada mas no cuando el cumplimiento no podrá ser posible como es el supuesto que se daría al demandarse la resolución ${ }^{98}$. Nos parece que primando en materia contractual el principio de la autonomía de la voluntad, si las partes expresamente estipularon una avaluación anticipada para esta clase de perjuicios implica que han previsto y distribuido anticipadamente los riesgos del incumplimiento, razón por la que debe prevalecer este acuerdo.

Sí estimamos necesario precisar el real alcance de esta cláusula penal moratoria en aquellos casos en que las partes no han pactado una suma única sino una fórmula de cálculo por cada día de retraso. Entendido el incumplimiento como una noción amplia y objetiva y asumiendo que no cualquier incumplimiento da lugar a la resolución del contrato sino sólo aquel que es grave y que denominamos resolutorio, una vez demandada la resolución ya no puede el acreedor fundarse en el retardo para seguir exigiendo la cláusula penal, ese retardo que

\footnotetext{
${ }_{96}$ La doctrina califica como fundamental en la institución de la cláusula penal el principio de la no acumulación, por todos, CORRAL (2012), pp. 260-261.

${ }^{97}$ Corral por su parte, tratándose de la que denomina pena compensatoria sustitutiva niega su procedencia ya que se produciría un enriquecimiento injusto si sobre la base del efecto retroactivo de la resolución se vulnera el principio de la no acumulación. En cambio, si se trata de una pena compensatoria indemnizatoria, el autor lo resuelve de forma diferente, la pena convencional será la avaluación anticipada de los perjuicios que el artículo 1489 permite acumular a la demanda resolutoria. Sí precisa el autor que si la cláusula ha sido expresa o implícitamente estipulada para cubrir los perjuicios consistentes en el valor de la prestación como los demás derivados a su falta, la cuestión se complejiza, pareciéndole la solución más justa reconocer que la cláusula penal puede demandarse conjuntamente con la resolución, Confróntese CORRAL (2012), pp. 266-267.

${ }_{98}$ En este sentido Corral estima que la pena moratoria no sería exigible, ella procede sólo cuando se pide el cumplimiento forzado de la obligación, ya que de pedirse la resolución en rigor no hay mero retardo sino incumplimiento definitivo. Considera que abona esta solución el principio de la retroactividad -que sin embargo no aplica a todos los casos- ya que el contratante diligente al hacer uso de la opción de resolver el contrato está pidiendo que éste se tenga por no celebrado y sería contradictorio que pida una pena fundado en una obligación que se consideraría no existente. CORRAL (2012), pp. 262-264.
} 
pudo ser un incumplimiento no grave, mantenido en el tiempo ha servido para configurar, ya sea objetivamente o subjetivamente el incumplimiento que da lugar a la resolución ${ }^{99}$. Será entonces el momento en que el acreedor opte por ejercer la facultad resolutoria el que limite la extensión de esta cláusula penal. En esta dirección la Corte de Apelaciones de Rancagua resolvió "[q]ue, a la luz de todo lo dicho, habida cuenta del tenor de la cláusula penal de la litis y que la misma se ha hecho efectiva en el contexto de la resolución del contrato de construcción, que importa descartar que éste llegue a cumplirse, no cabe sino entender que la mentada indemnización es de índole moratoria.

Lo anterior reviste capital importancia en este caso pues la indemnización moratoria se encuentra justificada en caso de que exista un retardo en el cumplimiento, es decir, el deudor ha cumplido, pero en forma tardía.

Sin embargo, aquí nos encontramos frente a un hecho distinto pues el cumplimiento ha devenido en imposible, debido a que el actor ha demandado la resolución del contrato y no su cumplimiento. Entonces, tratándose la indemnización penal pactada por las partes de una que se devenga día a día y no de una suma total y única, la pregunta que válidamente surge es ¿hasta cuándo se devengará dicha multa, si no se ha cumplido el contrato y no existe posibilidad de que ello ocurra?

Noveno: Que, en efecto, en este caso en concreto el cumplimiento no se ha retardado, la obligación no se ha cumplido ni se cumplirá en el futuro, por lo que la indemnización moratoria no podrá indemnizar el período que corre entre la mora y el cumplimiento, que es la forma como la concibe el Código Civil, específicamente en su artículo 1537 cuando señala que "ni constituido el deudor en mora, puede el acreedor pedir a un tiempo el cumplimiento de la obligación principal y la pena, sino cualquiera de las dos cosas a su arbitrio; a menos que aparezca haberse estipulado la pena por el simple retardo. "Es por ello, que cuando ha quedado establecido de manera inequívoca que el cumplimiento no se producirá, pues se ha demandado la resolución del contrato, desde ese momento ya no puede existir retardo". De este modo, sólo hasta ese momento le es válido al acreedor solicitar la pena pactada en el contrato y por ende, sólo a ello se dará lugar, negando en cambio lugar a aquellas que se devenguen durante la tramitación del juicio" ${ }^{\prime 100}$.

\footnotetext{
${ }^{99}$ Entendemos que el incumplimiento resolutorio se configura objetivamente teniendo en cuenta el impacto que produce el incumplimiento y sus consecuencias en el propósito que las partes perseguían con la celebración del contrato -que ha sido incorporado a éste-; y subjetivamente, cuando la conducta del deudor en la fase de ejecución del contrato conlleva una pérdida de confianza en el cumplimiento en los términos en que fue pactado. Sobre el particular, puede consultarse MejíAs (2012), pp. 209 y ss.

${ }^{100}$ Corte de Apelaciones de Rancagua, Rol № 432-2013, de 3 de diciembre de 2013, c. $8^{\circ}$ y $9^{\circ}$.
} 
Finalmente, consignamos que si la cláusula penal expresamente fue prevista como pena en caso de incumplimiento, la doctrina que se pronuncia sobre el particular, acepta de manera pacífica su procedencia en caso de resolución ${ }^{101}$, haciendo primar la autonomía de la voluntad de las partes, opinión que compartimos.

De esta forma, en las alternativas propuestas, los inconvenientes que pudieran generarse con la compatibilidad de los distintos tipos de cláusula penal y la resolución se resuelven, sin necesidad de acudir a los efectos retroactivos de la misma, por aplicación del principio del enriquecimiento sin causa.

\section{c. Hipótesis en que ninguna de las partes ha cumplido}

Este supuesto lo ha planteado la doctrina nacional ${ }^{102}$, teniendo a la vista la doctrina comparada ${ }^{103}$.

Una primera cuestión que en nuestro país se ha suscitado es si efectivamente la resolución es procedente si ninguno de los contratantes ha dado cumplimiento con sus prestaciones. Para la doctrina tradicional, que vincula indisolublemente el tenor del artículo 1552 con el artículo 1489 del Código civil e implícitamente con los requisitos para demandar la indemnización de perjuicios, se impone como un requisito más para que prospere la facultad resolutoria que el acreedor pruebe que ha cumplido o que se encuentra llano a hacerlo. En caso contrario, carecería de legitimidad para poder intentar la acción y, en la hipótesis que comentamos, ambos contratantes se verían impedidos de demandar la resolución del contrato ${ }^{104}$. Ahora bien, como la resolución no prosperará, el vínculo jurídico obligatorio solo podrá extinguirse conforme a los otros modos de extinguir las obligaciones, en especial la resciliación o mutuo disenso y la prescripción. El problema de esta corriente doctrinal es que en ambos casos se produce la dificultad de que la relación jurídica puede quedar indefinida en el tiempo. Si una de las partes ha demandado la resolución a la otra, es una clara señal que no han sido capaces de ponerse de acuerdo para que la resciliación opere ${ }^{105}$. Aquellos que consideran

\footnotetext{
101 Corral (2012), p. 268.

102 En especial Alcalde (2003), p. 18.

103 Clemente (1998), pp. 476 y ss.

104 Por todos, véase AlesSANDri (1931), pp. 689 y ss.

105 Confróntese, Rodríguez (2004 a), pp. 124-125. El autor menciona la prescripción porque estima que opera una verdadera resciliación tácita. Sin embargo, mientras corre el plazo de prescripción cualquiera de las partes puede cumplir o "allanarse" a cumplir y, en tal caso, pone de inmediato en funcionamiento la trama obligacional, abriendo camino a la ejecución forzada, la resolución y la indemnización de perjuicios.

Acude también a la prescripción como solución Abelıuk (2010), pp. 518-520.
} 
a la prescripción extintiva como el modo de extinguir las obligaciones aplicable, estiman que el cumplimiento del contrato de una de las partes o que se encuentre llano a hacerlo es, además un requisito de exigibilidad tanto de la pretensión de cumplimiento como de la resolución del contrato, que descansa en último término, en el cumplimiento simultáneo propio de las obligaciones bilaterales; obviándose que el cómputo de los plazos de prescripción de conformidad al artículo 2515 del Código civil se cuentan desde que la obligación se ha hecho actualmente exigible ${ }^{106}$. Más allá del plazo que debiera transcurrir, que conlleva que esta solución no sea económicamente la más eficiente, se produce un problema técnico jurídico: el plazo no podrá comenzar a correr porque la obligación no es actualmente exigible.

En el escenario descrito, para solucionar el problema práctico-jurídico que conlleva afirmar que la relación jurídica obligatoria se mantiene en suspenso, parte de la doctrina postula acudir a la caducidad de las condiciones ${ }^{107}$. Como es sabido, a propósito de las obligaciones condicionales indeterminadas, la doctrina discurre si realmente el hecho futuro e incierto en que consiste puede mantenerse de manera indefinida en el tiempo. Mayoritariamente se plantea su caducidad haciéndose primar la certeza jurídica más allá de la autonomía de la voluntad de las partes, es decir, existe un momento a partir del cual la condición debe reputarse fallida, sin perjuicio de que aún subsiste disparidad con relación a ese plazo: 5 años aplicando la regla del artículo 739 del Código civil, fundado en razones históricas o bien el plazo de 10 años, considerado como el máximo de incertidumbre que tolera nuestro ordenamiento jurídico ${ }^{108}$.

Los problemas que advertimos en esta postura son dos, uno jurídico y otro práctico. Desde la perspectiva jurídica, al entender a la facultad resolutoria como un mecanismo más de tutela frente al incumplimiento y no como una verdadera condición resolutoria desaparece el elemento comunicador relevante que nos permitiría aplicar analógicamente el artículo 739 del Código civil. Desde la perspectiva práctica, la relación sinalagmática se mantendrá en suspenso, a lo menos, por un plazo equivalente al general de extinción de las obligaciones.

Ciertamente, el verdadero problema se ha suscitado en los casos en que alguna de las partes ha dado cumplimiento con parte de su prestación y la otra no, de forma tal que de ambas puede decirse que no han cumplido totalmente o

\footnotetext{
106 Esta crítica ya la formulaba Rioseco a Rodríguez Grez. Confróntese, Rioseco (2004), pp. 296 y ss. En artículo posterior, el profesor criticado, precisa que la obligación sí es exigible mas su ejercicio es el que se mantiene suspendido por efecto de un hecho propio del deudor. Confróntese, Rodrícuez (2004 b), pp. 299-302. No obstante, esta aclaración mantenemos la crítica contenido en el cuerpo del trabajo.

107 Baraona (2009), pp. 380-382.

108 Confróntese, Peñallitlo (2012), pp. 361-363.
} 
cabalmente con sus prestaciones, produciéndose un efecto indeseado que atenta contra el sinalagma propio de los contratos bilaterales. Por esto nuestra doctrina ha intentado dar solución al problema práctico, planteado principalmente tratándose de contratos de promesas, acudiendo al principio del enriquecimiento sin causa, o a limitar el alcance del artículo 1552 o bien a la equidad como principio general del derecho, como una forma de colmar el vacío legal que se produciría porque este supuesto no está reglado en el Código civil. Esta última postura es la que han sostenido nuestros tribunales cuando estiman procedente la resolución, desde el año 1931 a partir de un comentario del profesor Alessandri, argumentación que se ha mantenido inalterada ${ }^{109}$.

Por nuestra parte, hemos sostenido en más una ocasión, que el único requisito que determina la procedencia de la resolución, ex artículo 1489 del Código civil, es la gravedad del incumplimiento. De esta forma habrá que

${ }^{109}$ En este sentido Elgueta Ortiz sostiene que no siendo aplicable el artículo 1552 por analogía, ella debe ser colmada sobre la base del fundamento del artículo 1489, cada parte contrata bajo una presuposición real, efectiva de que su contraparte ha de cumplir con su obligación y así aquélla podrá obtener la(s) ventaja(s) que se propuso y en consideración a la cual consintió en obligarse. Si la contraparte no cumple, la presuposición, que es el supuesto del contrato, falla y por eso la ley autoriza para pedir la resolución. El fundamento de la resolución para el autor es, por tanto, la falta del presupuesto que determina la voluntad de contratar. Confróntese, ElguetA (1947), pp. 94-96, 103 y ss. Por su parte, acuden a la equidad y al espíritu general de la legislación Peñailillo (2003), pp. 414-415 (este autor, además, agrega el carácter temporal de las obligaciones). AlCALDE (2003), pp. 387 y ss. Rodríguez Pinto considera que el recurso de los tribunales al espíritu general de la legislación y a la equidad natural es, en realidad, una aplicación del principio de que nadie puede enriquecerse injustamente a costa de otro en el supuesto de incumplimientos recíprocos, cuando una parte ha dado o pagado algo en virtud del contrato que pide resolver y lo que pretende obtener con la resolución es la restitución que la otra parte se niega a hacer. RODRícuez (2007), pp. 29-40.

Finalmente consignamos a Aguad para quien la mora del deudor no es requisito de la acción resolutoria, la norma del artículo 1552 sólo permite enervar la acción de cumplimiento y la pretensión indemnizatoria pero no la resolución. AGUAD (2006), p. 26.

La jurisprudencia que ha sostenido esta postura ha razonado partiendo de la premisa que no hay precepto alguno que resuelva la cuestión. Hace presente que los jueces están en el deber de juzgarla del modo que más conforme parezca al espíritu general de la legislación y a la equidad natural de acuerdo con lo preceptuado en el № 5 del artículo 170 del Código de Procedimiento Civil. La Corte Suprema ha sostenido que no parece justo ni equitativo dejar a las partes ligadas por un contrato que ambas no quieren cumplir y que de hecho aparece así ineficaz por voluntad de las mismas. Luego no pugna, con la índole y naturaleza de los principios jurídicos que informan la acción resolutoria que ella se acoja en estos casos, porque la resolución, es precisamente el medio que la ley otorga para romper un contrato que nació a la vida del derecho, pero que no está llamado a producir sus naturales consecuencias en razón de que las partes se niegan a respetarlo y todavía, porque acogiéndola se llega a la realidad propia de toda resolución, cual es que las cosas puedan restituirse al estado anterior, como si el contrato no hubiese existido, sin embargo no procede la indemnización de perjuicios pedida pues ella requiere de mora y en este caso no podría existir para ninguna de las partes de conformidad con lo dispuesto en el artículo 1552 del citado Código Civil. Corte Suprema, Rol No 512-2013, de 04 de diciembre 2003. Corte Suprema, Rol № 1744-2008, de 19 de agosto 2009. Corte Suprema, 29 de julio de 1931. 
determinar cuál de los incumplimientos es grave para facultar al contratante que lo sufre para demandar la resolución, teniéndose presente que estos incumplimientos pueden estar vinculados desde una perspectiva causal, proporcional o de entidad. Existen razones prácticas y jurídicas que avalan esta conclusión. Desde la perspectiva práctica, no parece razonable exigirle a un contratante que ejecute parte de su prestación, frente al incumplimiento de la otra, para poder demandar la resolución. Desde la perspectiva jurídica, hemos concluido en otra oportunidad, que existen razones históricas para diferenciar la excepción de contrato no cumplido y el tenor del artículo 1552 del Código civil, y que los efectos de uno y otro no se proyectan en el terrero de la resolución; la excepción de contrato no cumplido permite excepcionarse ante la pretensión de cumplimiento forzado, suspendiendo la prestación de las partes y el artículo 1552 impide constituir en mora al deudor, mora que conforme al artículo 1557 del Código civil es sólo requisito para demandar la indemnización de perjuicios ${ }^{110}$.

En aquellos casos en que el incumplimiento de las partes no se encuentre vinculado, sea totalmente independiente, coincidimos con aquella doctrina que plantea que estamos en presencia de una vacío o laguna legal que debe ser colmado, en atención a que el artículo 1489 del Código civil prevé un mecanismo de tutela para el caso en que uno de los contratantes no de cumplimiento a lo pactado y no ambos. De todas formas la resolución procede, pero el fundamento último es la equidad, no resulta equitativo mantener a las partes ligadas por un contrato que ninguna está dispuesta a cumplir.

Sea que los incumplimientos de las partes sean dependientes o independientes no resulta procedente una pretensión indemnizatoria porque ninguno de los contratantes puede considerarse constituido en mora.

Asumiendo que en estos casos la resolución es procedente, parte de la doctrina comparada afirma que la resolución no tiene efectos retroactivos ${ }^{111}$. Nos parece más preciso afirmar que no se justifica ninguna restitución entre las partes, porque ninguna ha dado cumplimiento con sus prestaciones. Sin embargo, en aquellos casos en que alguna de las partes dio cumplimiento parcialmente será necesario dar paso a obligaciones restitutorias para evitar enriquecimientos sin causa. En cualquier escenario, aparece descartada la necesidad de retrotraer a las partes al estado anterior al de la celebración del contrato.

Luego de haber analizado los casos que en doctrina se consideran emblemáticos en la inaplicabilidad del efecto retroactivo de la resolución, nos parece que, salvo en el caso de la cláusula penal, la negativa va de la mano de si se

110 Mejías (2014), pp. 111-156.

111 Clemente (1998), pp. 476 y ss. 
justifica o no un efecto restitutorio a consecuencia de la resolución. Se produce una suerte de identificación y asimilación entre el efecto retroactivo y las obligaciones restitutorias que puedan seguirse, identificación que también está presente en nuestros tribunales. En este sentido la Corte Suprema ha sostenido: "declarada como ha sido la resolución del contrato celebrado entre quienes ahora litigan, se ha impuesto la necesidad de que las partes queden restituidas al estatus jurídico que tenían antes de convenir. Surgen así, las obligaciones restitutorias $(. . .)^{\prime \prime 112}$.

Por nuestra parte, creemos conveniente precisar que no existen razones para esta identificación y asimilación. Como vimos, la retroactividad tiene su justificación en la estructura de las obligaciones sujetas a condición suspensiva como una forma de mantener la continuidad jurídica del derecho de que se trata, es decir, el derecho que se detenta en calidad de dueño desde el momento de la celebración o constitución del contrato o acto condicional y no desde que se verifica el hecho futuro e incierto de la condición. El escenario no es el mismo en la lógica de las condiciones resolutorias. Incluso, desde el prisma que lo hemos analizado, la retroactividad resulta descartada desde el momento en que la facultad prevista a favor del acreedor en el artículo 1489 del Código civil es un remedio más de éste frente al incumplimiento y no una condición. No puede ser equiparada esta situación a los efectos que la nulidad judicialmente declarada produce. Lo anterior ha conducido a la doctrina reciente a poner énfasis en que el efecto realmente propio de la resolución es el liberatorio, en virtud de él la parte que no ha ejecutado la prestación que era de su cargo, no tiene ya la obligación de realizarla ${ }^{113}$. En la doctrina nacional se reconoce este efecto a partir del artículo 1567, que prevé al cumplimiento de la condición como un modo de extinguir las obligaciones, mas no se ahonda en el mismo porque se considera un efecto evidente de la misma.

112 Corte Suprema, Rol No 7973-2013, de 9 de septiembre de 2013. En la misma dirección Corte Suprema, Rol № 1958-2010, de 13 de junio de 2011.

En doctrina hay autores que reconocen que la resolución no extingue el contrato sino las obligaciones primarias que de él derivan, mas vinculan la restitución con un efecto retroactivo. RodrícuEz-Rosado (2013), pp. 233 y ss. y ÁlvAREZ (1986), pp. 237 y ss. El autor justifica el efecto retroactivo en la evitación de un enriquecimiento sin causa.

113 Díez-Picazo (2008), p. 871 y Alcalde (2003), p. 4. Peñailillo por su parte, pone énfasis en que la retroactividad debe estar al servicio de la resolución acudiéndose a ella solo cuando sea indispensable para el propósito fundamental. Distingue el autor entre retroactividad en la existencia de la resolución y la retroactividad de sus efectos. Confróntese PeñAILILlo (2012), pp. 41 y ss. Reconociendo este efecto liberatorio Pizarro, además, se opone al efecto retroactivo, fundamentalmente porque el contrato que se pretende desaparecer contiene los elementos para configurar la resolución y modelar sus efectos, Confróntese PizArRo (2010), pp. 453-457. 


\subsection{El efecto restitutorio a que puede dar lugar la resolución por incumplimiento}

Declarada la resolución del contrato, pueden o no tener lugar obligaciones restitutorias. Determinar estos casos así como las normas y/o principios jurídicos que resultan aplicables es a lo que dedicaremos las líneas que siguen.

Ciertamente la obligación restitutoria no está consagrada a propósito de la resolución por incumplimiento, es sabido que carecemos de una regulación de sus efectos ${ }^{114}$. No dudamos de su procedencia, más coherente con lo ya afirmado, su fundamento, nos parece, está no en lo preceptuado por el legislador en las obligaciones condicionales sino en el principio del enriquecimiento sin causa. Como es sabido no existen normas legales que específicamente resuelvan los problemas planteados, sin que resulte suficiente una interpretación extensiva de las reglas referidas a la compraventa, prescindiendo incluso de aquellas propias de la condición resolutoria cumplida, porque -como vimos- buena parte de estas encuentran su explicación y justificación en el incumplimiento de la obligación de pagar el precio. Lo anterior nos conduce a considerar que existe un vacío o laguna legal que debe ser integrado y, en dicha integración, acudimos al principio del enriquecimiento sin causa ${ }^{115}$.

En sentido técnico el principio del enriquecimiento sin causa es un desplazamiento de valor que provoca un incremento patrimonial en determinado sujeto de derecho, a costa del patrimonio del otro, producido aparentemente de una manera conforme a derecho pero sin una causa o justificación que le sirva de base, y que atribuye al perjudicado una acción de restitución ${ }^{116}$. En

114 En la doctrina nacional Peñailillo da cuenta de la ausencia de un tratamiento autónomo en materia de efectos, PeÑailillo (2012), p. 46. El autor (pp. 43-45) formula interesantes criterios, extraídos de la normativa comparada, que pueden servir de base para una reforma de la materia, destacando: a) En relación con los frutos y compensaciones en dinero, factores como beneficios, necesidad o utilidad y los costos, asunción de riesgos, buena fe y el repudio al enriquecimiento sin causa; b) Con relación a las prestaciones, su posibilidad de restitución, utilidad de la prestación fundada en la preservación del contrato, repudio al enriquecimiento sin causa, y compensaciones en dinero.

En la doctrina española Rodríguez-Rosado partiendo de una premisa similar señala que antes de acudir al régimen legal de las condiciones para colmar un vacío legal es necesario examinar si esa aplicación es coherente con el funcionamiento de la resolución, RodríGuez-Rosado (2013), p. 235.

115 La justificación de la restitución en el principio del enriquecimiento sin causa ha estado siempre presente, incluso en los ordenamientos jurídicos que acogen la retroactividad, en las hipótesis en que la doctrina considera que esto no es posible en naturaleza. Confróntese Palazón (2009), p. 807; Serinet (2001), p. 613; BARROS (2009), pp. 33-36.

116 Monfort (2000), p. 88; Díez-Picazo (2011), p. 55; Peñallillo (2012), p. 9. Precisamos sí que el autor entiende que este principio es desplazado en materia de resolución y nulidad porque traen aparejado efecto restitutorio (p. 39).

La doctrina ha puesto de relieve que las hipótesis concretas de enriquecimiento sin causa difícilmente son subsumibles en un solo conjunto abstracto de supuestos. Es necesario darle una forma dogmática diferencia para evitar una excesiva generalización. Confróntese BARROS (2009), pp. 18-21. 
la materia que nos convoca el desplazamiento patrimonial o enriquecimiento se ha producido por la vía de una prestación, es decir, "se trata de dar marcha atrás en los efectos del comportamiento prestacional"117. El autor de la prestación realizó el desplazamiento patrimonial en cumplimiento de una obligación existente y la obligación restitutoria se funda en la frustración de la prestación por no producción o por desaparición de la finalidad a la que iba enderezada ${ }^{118}$. El alcance de la obligación restitutoria dependerá de la naturaleza de la prestación ya ejecutada en el contrato resuelto, es decir, si es una prestación de dar - una especie o cuerpo cierto- o una cosa genérica, o bien una obligación de hacer o no hacer. En línea de principios la restitución deberá hacerse in natura y en aquellos casos en que no sea posible, procederse a un equivalente pecuniario fundado, una vez más, en el enriquecimiento sin causa ${ }^{119}$. En ambos casos la obligación restitutoria es manifestación de una obligación de dar ${ }^{120}$.

117 Dí́z-PıCazo (2011), p. 151. Emplea el autor un concepto de prestación que es aplicable al "Derecho del Enriquecimiento" donde es esencial el resultado de aumento patrimonial.

118 Confróntese Dí́z-Picazo (2011), pp. 152-158. El autor distingue en la condictio de la prestación: la condictio indebiti, la condictio ob causam finitiam, la condictio ob rem y la condictio ob turpem vel iniustam causam. La restitución a que da lugar la resolución la sitúa en la segunda porque en ellas existía causa al momento en que fue ejecutada la prestación pero esta después desaparece. No obstante, el autor vuelve a hacer presente la aplicación de las reglas de las obligaciones condicionales. Precisamos que adherimos a la doctrina que entiende como requisitos del enriquecimiento sin causa dos: el enriquecimiento de un sujeto y la ausencia de causa que lo justifique. Confróntese Peñallitlo (2012), pp. 12 y ss.

119 Con relación a la obligación restitutoria, DíEz-PiCAzo (2008), p. 872 y Clemente (1998), pp. 535-536. En la doctrina nacional Castelblanco precisa que se está ante una obligación restitutoria cada vez que la prestación a que se encuentra obligado un sujeto consista en la devolución de una cosa, en el reembolso de un valor, ya sea que provenga de restituir de la normal ejecución de un acto o contrato, o de la ley o porque los principios de equidad así lo aconsejan, como en el caso de la acción de in rem verso. Diferimos sí del autor que asume que la resolución da lugar a una obligación restitutoria mas sigue identificándola con efectos retroactivos y con las obligaciones condicionales. CASTELBLANCO (1972), pp. 37 y ss.

En la doctrina española, Monfort concluye que el Código civil emplea el término "restituir" en distintos supuestos, perfectamente distinguibles entre nosotros, a saber: 1) Una restitución con carácter general, que supone la restitución de un bien ajeno que se detenta sin derecho y sin importar el título por el que se posee. 2) Restitución de bienes en razón de pérdida de eficacia del título por el que se posee-aquí sitúa al artículo 1124-. 3) Restitución de bienes en razón de un título preferencial cuya eficacia queda dilatada en el tiempo. 4) Restitución derivada de la obligación de re-entrega en contratos o derechos reales caracterizados por la cesión del uso temporal a un tercero en concepto distinto del de dueño. 5) Entrega de bienes en cumplimiento de una obligación de dar. Confróntese MONFORT (2000), pp. 77-81. A nuestro juicio la obligación restitutoria emanada de la resolución por incumplimiento corresponde al primer caso. Se precisa sí que la autora sitúa en el enriquecimiento sin causa el fundamento de la restitución, postulando su aplicación al menos de modo subsidiario (pp. 87-107).

120 Castelblanco (1972), pp. 39-40; Peñallillo (2012), pp. 50 y ss. 
Nos parece que si la obligación es de hacer o de no hacer y se ha dado cumplimiento parcialmente con la obligación, por la propia naturaleza de la prestación concernida, la restitución se concretará en un equivalente pecuniario ${ }^{121}$.

Si la obligación incumplida que motivó la resolución y que conlleva ahora la obligación de restituir es de dar, habrá que efectuar algunas precisiones:

\section{a. Si la obligación es de dar una especie o cuerpo cierto}

Conforme a la restitución en naturaleza que hemos postulado deberá darse primacía a esta, mas cuando sea imposible el deudor estará obligado a restituir su valor.

La imposibilidad podrá ser fortuita o culpable y entendemos que en ambos casos la solución es la misma. No postulamos, por ende, como lo ha hecho parte de la doctrina distinguir el momento en que se ha producido la pérdida de la cosa -antes o después del ejercicio de la facultad resolutoria ${ }^{122}$ - o si esto se debe o no a imputabilidad en la conducta del deudor. La razón de esto, descansa por una parte, en que entendemos que las reglas que gobiernan la pérdida de la cosa que se debe, como modo de extinguir las obligaciones, no tiene aplicación directa o automática en la estructura de los contratos bilaterales, caracterizados por la reciprocidad e interdependencia de las obligaciones que de él emanan. Extinguida la obligación de una de las partes por imposibilidad sobrevida de la prestación no imputable o debida a un caso fortuito, en estricto sentido, sólo nos cuestionamos acerca de la suerte que corre la obligación correlativa y en este escenario, la mayoría de la doctrina se inclina por sostener la solución más acorde a la estructura de estas obligaciones: el res perit debitori ${ }^{123}$. Ahora bien, si el contrato es resuelto y la prestación que una de las partes debe restituir sobreviene en imposible, las alternativas posibles -coherente con lo sostenido- es que ambas obligaciones se tengan por extintas o que ambas subsistan, debiendo otorgarse un equivalente pecuniario -restitución en valor- para evitar un enriquecimiento sin causa.

Por otra parte, no debe perderse de vista en esta equiparación que efectuamos entre una imposibilidad fortuita de una culpable, que la resolución no conlleva un problema de ineficacia sobrevenida del contrato. Ella no produce efectos retroactivos y no es necesario proceder como si el contrato jamás se hubiese celebrado. Sí pueden tener lugar obligaciones restitutorias que fundadas

121 Rodríguez-Rosado (2013), pp. 240-241; Alcalde (2003), p. 16.

122 Clemente (1998), pp. 535-546.

${ }^{123}$ Fuera de los casos en que le ley impone que el riesgo es de cargo del acreedor, de conformidad a los artículos 1550 y 1820 del Código civil, aquellos en que la prestación es de dar una especie o cuerpo cierto. Por todos Elorriaga (2002), pp. 34 y ss.; Abeliuk (2010), pp. 1175-1186. 
en el enriquecimiento sin causa no descansan en la culpa o imputabilidad del enriquecido sino que opera de manera objetiva ${ }^{124}$.

Equiparamos los supuestos de imposibilidad no solo cuando la especie o cuerpo cierto, conforme las reglas generales -artículo 1670 del Código civildesaparece, se ha destruido o esté fuera del comercio humano, sino también cuando la posesión y/o dominio lo han adquirido terceros de buena fe, en virtud de un título translaticio de dominio, que además, sea oneroso. Creemos que en estos casos, como ya lo habíamos adelantado, debe primar la protección de la apariencia jurídica ${ }^{125}$. Esta solución se concilia de mejor manera con la protección de tráfico jurídico y no violenta la presunción general de buena fe que consagra nuestro Código civil, como si advertimos lo hace -a nuestro juicio- la interpretación tradicional de los artículos 1490 y 1491 del Código civil.

En aquellos casos en que no estemos en presencia de una destrucción de la cosa sino simplemente de su deterioro, será procedente el pago del valor de este deterioro.

Tratándose de los frutos, como ya se consignó, en virtud del principio del enriquecimiento sin causa entendemos que aquellos percibidos con anterioridad a que haya operado la resolución corresponderán al deudor de la obligación de restituir, con posterioridad, al acreedor de esta obligación.

En cualquiera de estas hipótesis, para evitar un enriquecimiento sin causa deberá procederse el pago al deudor de las mejoras necesarias que haya efectuado porque de todas formas el dueño o poseedor las hubiese tenido que realizar ${ }^{126}$.

\section{b. Si la obligación es de dar una cosa genérica}

En estos casos por la propia naturaleza de la prestación, resulta razonable reconocerle al deudor de la obligación de restitución la facultad de restituir una cantidad equivalente de aquel género que recibió en una calidad, al menos mediana, o su valor ${ }^{127}$.

124 Díez-Picazo (2011), p. 55. Parte de la doctrina exige la ausencia de imputabilidad del empobrecido como requisitos indispensable del enriquecimiento sin causa y con esto de la acción restitutoria que se prevé. En este sentido PeÑallillo (2012), pp. 20 y ss., y López (2003), pp. 378 y ss. Si es importante precisar que los autores no tienen como modelo el de la resolución sino que se plantea en términos generales que el empobrecido no tiene que haber actuado con dolo o culpa para que prospere la acción de restitución.

125 Peñailillo considera que la directriz en la materia debe ser la protección de la apariencia jurídica. Peñallillo (2012), pp. 48 y ss.

126 En la misma dirección tratándose de las mejoras y frutos Rodríguez-Rosado (2013), p. 238.

127 SERINET (2001), p. 596. 
Entendemos que de esta forma se concilian adecuadamente los distintos intereses en juego: el de las partes y de los terceros, que es coherente con la resolución como un mecanismo de tutela del acreedor lesionado por el incumplimiento, que facilita la finalidad que se persigue con su ejercicio, esto es, realizar una operación de reemplazo; sin necesidad de mantener complejas reglas cuya estructura se justifica, en especial, en la figura de las obligaciones sujetas a condición suspensiva.

\subsection{Los efectos de la resolución en el nuevo derecho de la contratación}

Para finalizar nuestro análisis acerca de los efectos de la resolución, nos parece ilustrador exponer la forma en que el nuevo derecho de la contratación los regula. En este escenario es relevante destacar la regulación que proporciona, en especial, la Convención de Viena sobre compraventa internacional de mercaderías porque es Ley de la República. Tomando esta de modelo, haremos presente las semejanzas y diferencias en la regulación que brindan los Principios de Derecho Contractual Europeo, los Principios de Unidroit sobre Contratos Comerciales Internacionales y el Marco Común de Referencia ${ }^{128}$.

La CVCIM dedica la sección 5a, del Capítulo V, Parte III a la regulación de los efectos de la resolución, en sus artículos 81 a 84 . El artículo 81 comienza consagrando el efecto liberatorio que se le atribuye, de manera tal que verificada la resolución del contrato ninguna de las partes se encuentra ya obligada a cumplir con las prestaciones que emanaban del mismo ${ }^{129}$. Continúa estableciendo la obligación restitutoria en caso que se haya dado cumplimiento total o parcialmente al contrato, obligación que debe cumplirse simultáneamente si ambas partes deben restituir. En esta regulación la facultad misma de resolver está supeditada a que el comprador pueda restituir las mercaderías en un estado sustancialmente idéntico a aquel en la que las hubiese recibido -artículo 82 $1)^{130}-$, sin perjuicio de una serie de excepciones que contempla el numeral 2 del artículo 82.

${ }^{128}$ En los sucesivo CVCIM, PECL, PCCl y MCR, respectivamente.

129 El artículo 81 dispone: "1) La resolución del contrato liberará a las dos partes de sus obligaciones, salvo a la indemnización de daños y perjuicios que pueda ser debida.

La resolución no afectará a las estipulaciones del contrato relativas a la solución de controversias ni a ninguna otra estipulación del contrato que regule los derechos y obligaciones de las partes en caso de resolución.

2) La parte que haya cumplido total o parcialmente el contrato podrá reclamar a la otra parte la restitución de lo que haya suministrado o pagado conforme al contrato. Si las dos partes están obligadas a restituir, la restitución deberá realizarse simultáneamente".

130 En la Convención tanto el ejercicio de la facultad resolutoria como aquellos casos en que el comprador exige una entrega sustitutiva está condicionada a la restitución de los bienes recibidos, sin 
El artículo 84 se encarga de reglar la forma en que debe tener lugar la restitución ${ }^{131}$. En el caso del comprador, debe abonar al vendedor el importe de todos los beneficios que haya obtenido de las mercaderías o de una parte de ellas, sea que deba restituirlas o se encuentre imposibilitado de hacerlo. En el caso del vendedor, este debe restituir el precio incluyendo el abono de los intereses correspondientes a partir de la fecha en que se haya efectuado el pago. Respecto del momento de estos intereses, su determinación, corresponderá al derecho nacional que resulte aplicable de conformidad a las reglas de derecho internacional privado ${ }^{132}$.

Se advierte en la regulación de la CVCIM que la resolución no produce efectos retroactivos, no es necesario retrotraer a las partes al estado anterior a la celebración del contrato ${ }^{133}$, es más, su artículo 81 expresamente contempla que esta no afecta el valor de las cláusulas previstas por las partes especialmente para el caso de incumplimiento o resolución. En esta dirección, Tallon afirma que la redacción de la disposición no plantea, en términos abstractos, el problema de la retroactividad, aunque implica la desaparición retrospectiva del contrato, lo

perjuicio de que queda abierta la posibilidad de ejercer los otros derechos que contempla la CVCIM. Confróntese SCHLECHTRIEM (1986).

131 El artículo 82 dispone: "1) El comprador perderá el derecho a declarar resuelto el contrato o a exigir al vendedor la entrega de otras mercaderías en sustitución de las recibidas cuando le sea imposible restituir éstas en un estado sustancialmente idéntico a aquél en que las hubiera recibido.

2) El párrafo precedente no se aplicará: a) si la imposibilidad de restituir las mercaderías o de restituirlas en un estado sustancialmente idéntico a aquél en que el comprador las hubiera recibido no fuere imputable a un acto u omisión de éste;

b) si las mercaderías o una parte de ellas hubieren perecido o se hubieren deteriorado como consecuencia del examen prescrito en el artículo 38; o

c) si el comprador, antes de que descubriera o debiera haber descubierto la falta de conformidad, hubiere vendido las mercaderías o una parte de ellas en el curso normal de sus negocios o las hubiere consumido o transformado conforme a un uso normal".

El artículo 83 dispone: "El comprador que haya perdido el derecho a declarar resuelto el contrato o a exigir al vendedor la entrega de otras mercaderías en sustitución de las recibidas, conforme al artículo 82, conservará todos los demás derechos y acciones que le correspondan conforme al contrato y a la presente Convención".

El artículo 84 dispone: 1) El vendedor, si estuviere obligado a restituir el precio, deberá abonar también los intereses correspondientes a partir de la fecha en que se haya efectuado el pago.

2) El comprador deberá abonar al vendedor el importe de todos los beneficios que haya obtenido de las mercaderías o de una parte de ellas: a) cuando deba restituir las mercaderías o una parte de ellas; o b) cuando le sea imposible restituir la totalidad o una parte de las mercaderías o restituir la totalidad o una parte de las mercaderías en un estado sustancialmente idéntico a aquél en que las hubiera recibido, pero haya declarado resuelto el contrato o haya exigido al vendedor la entrega de otras mercaderías en sustitución de las recibidas".

132 Clemente (1998), p. 489; SChlechtriem (1986).

133 SChlechtriem (1986); Montes (1998), pp. 660-670. 
que se traduce en la aplicación de las reglas conocidas en el derecho francés a propósito de la repetición (condictio indebiti) o, más ampliamente, de la repetición por enriquecimiento injusto ${ }^{134}$.

Sus efectos se proyectan sólo con relación a las partes ya que no están previstas las consecuencias que puedan seguirse con relación a los terceros, estas se rigen por el derecho nacional ${ }^{135}$.

En dirección similar los PECL (artículo 9:305) y los PCCI (artículo 7.3.5) no atribuyen en principio efecto retroactivo a la resolución, este tiene más bien un carácter excepcional; se considera por los autores poco adecuado equiparar los casos de resolución a los casos de nulidad o de cancelación que implican tener el contrato como si nunca hubiese existido porque, por una parte, se podría afectar la posibilidad de demandar una indemnización de perjuicios o su extensión; y, por otra, se restaría eficacia a aquellas cláusulas previstas para ser aplicadas en caso de resolución ${ }^{136}$.

Se reitera que el efecto propio es el liberatorio, y de inmediato el artículo 9:305 de los $\mathrm{PECL}^{137}$ explicita que no afecta los derechos y obligaciones que ya habían nacido al momento de la resolución, ni las cláusulas de resolución de controversias ni otra destinada a producir efectos tras la resolución. Los $\mathrm{PUCl}$, además, expresamente dejan a salvo el derecho a reclamar una indemnización de perjuicios por el incumplimiento producido (artículo 7.3.5 (2) ${ }^{138}$ ). Ambos los contempla el MCR en su artículo 3:509.

\footnotetext{
134 TALLON (1987), p. 604.

135 TALLON (1987), p. 601.

136 Lando y Beale (2003), p. 618.
}

En esta dirección se orienta también la Propuesta de Modernización del Código civil español en la materia. El artículo 1203 consagra el efecto restitutorio, restitución que se prevé como simultánea. Se reconoce que la resolución no puede hacer desaparecer todos los efectos del contrato (artículo 1202) y se prevén una serie de supuestos de irretroactividad: si ninguna de las partes ha dado cumplimiento con las prestaciones o se está ante la resolución de un contrato preparatorio. Confróntese CLEMENTE (2011), pp. 1-16. En los proyectos de reforma al Code civil las soluciones no son idénticas, así el Proyecto Terré suprime el carácter retroactivo a la resolución, en cambio el Projet de réforme du droit des obligations (Texte du projet de la Chancellerie) artículos 171 relacionado con el 103 contempla estos efectos, de manera similar el artículo 1160 del Avant-projet de réforme du Droit des obligations et de la prescription. Sobre la regulación de la resolución en estos proyectos puede consultarse PizARRO (2011), pp. 132-135.

137 El artículo 9:305 dispone: “(1) La resolución del contrato libera a ambas partes de la obligación de cumplir y de recibir futuras prestaciones, pero de acuerdo con los artículos 9:306 a 9:308, no afecta a los derechos y obligaciones que se hubieran generado hasta el momento de la resolución.

(2) La resolución no afecta para nada a las estipulaciones previstas en el contrato para la solución de conflictos, ni a cualesquiera otras cláusulas que deban surtir efecto incluso tras la resolución".

${ }^{138}$ El artículo 7.3.5 dispone: "(1) La resolución del contrato releva a ambas partes de la obligación de efectuar y recibir prestaciones futuras. 
Sí se prevén obligaciones restitutorias, ya del dinero pagado ya de bienes entregados (artículos 9:307 y 9:308 PECL y 7.3.6 PCCI, ·3:511 MCR). Los COmentaristas de los PECL señalan que el efecto restitutorio es consecuencia de la retroacción del efecto desvinculador, obliga a devolverse las prestaciones ya realizadas en los casos en que la resolución hace que jurídicamente dejen de estar justificadas ${ }^{139}$. Los PECL, los PCCI y MCR se encarga de establecer el pago de un importe razonable por el valor de la prestación en caso que sea ésta imposible de restituir, se advierte aquí una diferencia con lo que prevé el artículo 82 CISG que, como vimos, supedita la procedencia de la resolución a la posibilidad de restitución de la prestación. Tampoco se regulan en estos principios los efectos con relación a terceros, queda una vez más entregado a los derechos nacionales.

En definitiva, resulta patente que en ninguno de estos cuerpos la retroactividad surge como una consecuencia necesaria del remedio resolutorio.

\section{Conclusiones}

Luego del análisis que hemos efectuado las conclusiones a las que se han arribado son las que siguen:

1. El Código civil no consagra expresamente un efecto retroactivo en el caso de la condición resolutoria cumplida. Sólo se prevén efectos restitutorios -ex artículo 1487-y es por esto que la doctrina se ve en la necesidad de mencionar constantes excepciones al mismo.

2. Entre nosotros ha primado el tratamiento conjunto de los efectos de las condiciones, tanto suspensivas como resolutorias, aun cuando la regulación que el legislador proporciona se aviene más con la estructura de la condición suspensiva.

3. La facultad resolutoria que consagra el artículo 1489 del Código civil no es realmente una condición y, por esto, tratándose de los efectos de la resolución judicialmente declarada, no es posible colmar el vacío o laguna legal que se produce -ante la ausencia de normativa- acudiendo por analogía a las reglas de las condiciones. No existe una igualdad jurídica esencial para poder extraer reglas que sean aplicables a las restituciones, a que puede dar lugar la resolución por incumplimiento.

(2) La resolución no excluye el derecho a reclamar una indemnización de los daños y perjuicios causados por el incumplimiento.

(3) La resolución no afecta cualquier término del contrato relativo al arreglo de controversias o cualquier otra cláusula del contrato destinada a operar aún después de haber sido resuelto".

139 Díez-Picazo et al. (2002), pp. 365-366; Lando y Beale (2003), p. 621. 
Las reglas de la compraventa, si bien norman un caso de resolución por incumplimiento, carecen de la generalidad que se requiere para que pueda operar la analogía, se trata de disposiciones que se explican en el incumplimiento de la obligación de pagar el precio por parte del comprador y que son coherentes con su particularidades.

4. No existen razones históricas ni lógicas que obliguen a mantener una eficacia retroactiva en la resolución judicialmente declarada. La doctrina que tradicionalmente le ha atribuido este efecto reconoce una serie de excepciones que confirman la imposibilidad de tener al contrato como no celebrado. Los efectos propios de esta institución son, por una parte, el efecto liberatorio y, por otra, el efecto restitutorio.

5. Las obligaciones restitutorias a que puede dar lugar la resolución entre las partes se fundan en el principio del enriquecimiento sin causa y no en la exigencia de retroactividad. Por esto, si una de las partes ha dado cumplimiento con su prestación, la otra debe restituir en especie o en su equivalente pecuniario, en los casos de imposibilidad, sea esta fortuita o culpable.

Existe imposibilidad de restituir, por regla general, tratándose de las obligaciones de hacer y no hacer y en las obligaciones de dar una especie o cuerpo cierto cuando ésta desaparece, se ha destruido o esté fuera del comercio humano y cuando la posesión y/o dominio lo han adquirido terceros de buena fe, en virtud de un título translaticio de dominio, que además, sea oneroso, prima en este último caso la protección de la apariencia jurídica.

Tratándose de los frutos, en virtud del principio del enriquecimiento sin causa, sólo corresponden al acreedor de la obligación de restitución, aquellos que son posteriores a la declaración judicial de resolución. En virtud de este mismo principio deberá pagarse al deudor las mejoras necesarias que haya efectuado porque de todas formas el dueño o poseedor las hubiese tenido que realizar.

6. Situados en los efectos de la resolución respecto de los terceros, la interpretación que tradicionalmente ha dado la doctrina, a partir del tenor de los artículos 1490 y 1491 del Código civil, no tutela el tráfico jurídico y contraviene la presunción general de buena fe que consagra nuestro Código civil. Se considera que la facultad resolutoria es una condición tácita y como tal los terceros siempre han debido tener conocimiento de ella. A nuestro parecer la regla y el principio que se extrae de estas disposiciones, teniendo en consideración además, la teoría de la apariencia jurídica, es que los terceros que han contratado de buena fe a título oneroso, sea que la cosa adquirida por tradición sea mueble o inmueble, no se verán obligados a restituir. En estos casos el problema de los efectos quedan circunscritos entre la partes al configurarse un caso de imposibilidad de restituir en naturaleza la prestación. 


\section{BiBLIOGRAFÍA CITADA}

Abeliuk Manasevich, René (2010): Las obligaciones (Santiago, Editorial Jurídica), tomo I.

AlesSAndri Rodríguez, Arturo (1988): Teoría de las obligaciones (Santiago, Editorial Jurídica de Chile).

_ (2003): De la compraventa y de la promesa de venta (Santiago, Editorial Jurídica), tomo II.

— (2009): De los contratos (Santiago, Editorial Jurídica de Chile).

Alessandri Rodríguez, Arturo; Somarriva Undurraga, Manuel; Vodanovic Haklicka, Antonio (1998): Tratado de derecho civil, parte general y especial (Santiago, Editorial Jurídica de Chile).

Alessandri, Arturo; Somarriva, Manuel (2005): Tratado de los derechos reales ${ }^{6}$ (Santiago, Editorial Jurídica de Chile), tomo II.

Álvarez Vigaray, Rafael (1986): La resolución de los contratos bilaterales por incumplimiento (Granada, Editorial Comares).

Baraona González, Jorge (2009): "Algunas consideraciones sobre el retraso en el cumplimiento de las obligaciones: su configuración y eficacia", en: Pizarro Wilson, Carlos (editor), Estudios de Derecho civil V (Santiago, LegalPublishing), pp. 369-384.

Barros Bourie, Enrique (2007): "Finalidad y alcance de las acciones y los remedios contractuales", en: GuZMán Brito, Alejandro, Estudios de derecho civil III (Valparaíso, LegalPublishing), pp. 311-334.

(2009): "Restitución de ganancias por intromisión en derecho ajeno, por incumplimiento contractual y por ilícito extracontractual", en: BARROs BOURIE, Enrique; García Rubio, María Paz, Morales Moreno, Antonio, Derecho de Daños (Madrid, Fundación Coloquio Jurídico Europeo).

Bello, Andrés (1887): Obras Completas de don Andrés Bello (Santiago, impreso por Pedro G. Ramírez), tomos XI y XIII.

Boetsch Gillet, Cristián (2011): La buena fe contractual (Santiago, Editorial Jurídica de Chile).

Castelblanco Koch, Javier (1972): Las obligaciones restitutorias del Código civil y la inflación (Santiago, Editorial Jurídica de Chile).

Claro Solar, Luis (1978): Explicaciones de Derecho Civil Chileno y comparado, $X$ : De las Obligaciones (Santiago, Imprenta El Imparcial).

Clemente Meoro, Mario (1998): La facultad de resolver los contratos por incumplimiento (Valencia, Tirant lo Blanch). 
CORRAL, Hernán (2012): "La cláusula penal" función y eficacia del contrato penal en el derecho chileno (Santiago, Editorial Jurídica de Chile).

Dízz Duarte, Raúl (1988): La compraventa en el Código civil chileno (Santiago, Editorial Jurídica de Chile).

Del VeCCHIO, Giorgio (1971): Los principios generales del derecho 3 (Traducc. de Juan Osorio Morales, Barcelona, Editorial Bosch).

Díez-PICAzo y Ponce de León, Luis (2008): Fundamentos del derecho civil patrimonial $^{6}$ (Madrid, Civitas), tomo II.

__ (2011): La doctrina del enriquecimiento sin causa (Bogotá, Pontifica Universidad Javeriana).

Díez-Picazo, Luis; Roca Trías, Encarna; Morales Moreno, Antonio Manuel (2002): Los principios del Derecho Europeo de Contratos (Madrid, Civitas).

Elgueta Ortiz (1947): Augusto, La resolución y el incumplimiento recíproco (Memoria Licenciatura, Universidad de Chile, Santiago).

Eloriaga de Bonis, Fabián (2002): "La teoría de los riesgos", en Fundación Fernando

FueYo LANeri, Estudios sobre reformas al Código civil y Código de comercio (Santiago, Editorial Jurídica de Chile), tomo II.

FueYo LANERI, Fernando (1958): Derecho civil IV (Santiago, Imprenta y Litografía Universo), tomo I.

- (2004): Cumplimiento e incumplimiento de las obligaciones ${ }^{3}$ (Santiago, Editorial Jurídica de Chile).

Gatica Pacheco, Sergio (1959): Aspectos de la indemnización de perjuicios por incumplimiento del contrato (Santiago, Editorial Jurídica de Chile).

Guzmán Brito, Alejandro (2013): Derecho Privado Romano (Santiago LegalPublishing), tomo II.

HinOSTROSA, Fernando (2008): "Las restituciones consecuenciales a la eliminación del contrato", en: Mantilla Espinosa, Fabricio; Pizarro Wilson, Carlos (Editores), Estudios de derecho privado en homenaje al profesor Christian Larroumet (Santiago, Fundación Fueyo).

Lando, Ole; Beale, Hugh (2003): Principios de Derecho contractual Europeo - Los trabajos de la "Comisión de Derecho contractual europeo (Madrid, Consejo General del Notariado).

López SANTA María, Jorge (2005): Contratos: parte general (Santiago, Editorial Jurídica de Chile), tomo II.

MejíAs Alonzo, Claudia (2011): El incumplimiento resolutorio en el Código civil (Santiago, LegalPublishing).

Monfort FerRero, María Jesús (2000): La restitución en la resolución por incumplimiento de los contratos traslativos del dominio (Valencia, Tirant lo Blanch). 
Montes, Vicente (1998): "Comentario al art. 81", en Díez-Picazo y Ponce de León (coordinador), La compraventa internacional de mercaderías, comentario de la Convención de Viena (Madrid, Civitas).

Palazón Garrido, María Luisa (2009): "La resolución del contrato como medio de tutela en caso de incumplimiento", en: SÁnChez Lorenzo, Sixto, Derecho contractual Europeo (Navarra, Aranzandi).

Peñallillo Arévalo, Daniel (1999): La protección de la apariencia en el derecho civil (Concepción, Universidad de Concepción).

— (2010): Los bienes (Santiago, Editorial Jurídica de Chile).

PIZARRo WiLSON, Carlos (2010): "Contra el efecto retroactivo de la resolución por incumplimiento", en: Elorriada De BonIs, Fabián, Estudios de Derecho Civil VII (Santiago, Abeledo Perrot), pp. 449-460.

PothieR, Joseph (1878): Tratado de las Obligaciones (Traducc. S.M.S, Barcelona, Librería de Álvaro Verdaguer).

Rodríguez Pinto, María Sara (2007): "El principio "nadie debe hacerse más rico en detrimento de otro" $(\mathrm{D} .12,6,14)$ en la resolución de un contrato de promesa por incumplimientos recíprocos: una tendencia jurisprudencial chilena", en; Corral Talciani, Hernán y Rodríguez Pinto, María Sara [a cura di], Estudios de derecho civil Il Código civil y principios generales: nuevos problemas, nuevas soluciones (Santiago, LegalPublishing), pp. 29-40.

RodríGuez-Rosado, Bruno (2013): Resolución y sinalagma contractual (Madrid, Marcial Pons).

SChleChtRIEM, Peter (1986): "Uniform Sales Law - The UN-Convention on Contracts for the International Sale of Goods", en: Institute of International Commercial Law, disponible en: http://www.cisg.law.pace.edu/cisg/biblio/ schlechtriem-81.html [visitado el 26/12/ 2014].

SERINET, Yves-Marie (2001): "L’effet rétroactif de la résolution pour inexécution en droit français", en: FontaIne, Marcel; VINEY, Geneviève (editores), Les sanctions de l'inexécution des obligations contractuales (Paris, L.G.D.J.).

Squella Narduccl, Agustín (2014): Introducción al Derecho (Santiago, LegalPublishing).

TAlLoN, Denis (1987): Article 81, en: Commentary on the International Sales Law, disponible en: http://www.cisg.law.pace.edu/[isg/biblio/tallon-bb81. html [visitado el 30/12/2014].

Treitel, Gunter (2004): The Law of contract (New York, Oxford University Press). Vío VÁsquez, Efraín (1945): Las obligaciones condicionales (Memoria Licenciatura, Universidad de Concepción. 
WHITTAKER, Simon (2001): "Les sanctions de l'inexécution des contrats, droit anglais", en: Fontaine, Marcel; Viney Genes (Editores), Les sanctions de l'inéxecution des obligations contractualle, Etudes de droit comparé (Paris, L.G.D.J.).

\section{B. Artí́culos de Revistas}

Aguad Deik, Alejandra (2006): "Algunas reflexiones sobre los efectos del incumplimiento recíproco frente a la acción resolutoria", en: Revista Chilena de Derecho Privado (No 2), pp. 9-28.

Alcalde Rodríguez, Enrique (2003): “Distinción entre obligaciones principales y secundarias y consecuencias de tal distinción en relación con la resolución de un contrato bilateral", en: Revista Chilena de Derecho (año 30, № 2), pp. 387-397.

Alcalde Silva, Jaime (inédito), Los efectos de la resolución por incumplimiento en el derecho chileno (artículo inédito, gentilmente facilitado por su autor).

Alessandri Rodríguez, Arturo (1931): "Comentario sentencia 21 julio año 1931", en: Revista de Derecho y Jurisprudencia (Tomo 28, № 2), pp. 689 y ss.

BÉCAR LABRAÑA, Emilio (2010): "Revisión crítica de la retroactividad como factor operativo de la resolución del contrato: algunas perspectivas de reforma para el derecho chileno", en: Revista de Derechos y Humanidades (Año $\left.16, N^{\circ} 2\right)$, pp. 133-152.

Cerdeira Bravo de Mansilla, Guillermo (2012): "Analogía e interpretación extensiva: una reflexión (empírica) sobre sus confines", en: Anuario de Derecho Civil (Año 65, № 3), pp. 1001-1073.

Fenor Picón, Nieves (2011): “La modernización del régimen del incumplimiento del contrato: propuestas de la Comisión General de Codificación. Parte segunda. Los remedios del incumplimiento", en: Anuario de Derecho Civil (Año 64, No 4), pp. 1481-1684.

LAzO, Patricio (2006): "El pretendido efecto retroactivo de la condición cumplida", en: Revista Chilena de Derecho (Año 33, № 3), pp. 561-583.

LOPEZ, Marcelo (2013): "El enriquecimiento sin causa en el derecho actual (Las posibilidades y los límites de un instituto controversial)", en: Anuario da Facultade de dereito da Universidades da Cataluña ( $N^{\circ} 13$ ), pp. 363-398.

Mejías Alonzo, Claudia (2014): "La excepción de contrato no cumplido, un análisis de su aplicación en la jurisprudencia nacional reciente y en la doctrina", en: Revista de Derecho Universidad Católica del Norte 21 (2014) 1, pp. 111-156.

Peñallitlo, Daniel (2012): "Algunas reformas a la resolución por incumplimiento", en: Revista de Derecho Universidad de Concepción (№ 231-232), pp. 7-60. 
Pizarro Wilson, Carlos (2011): "Los remedios al incumplimiento contractual en los proyectos franceses de reforma del Derecho de contratos", en: Revista de Derecho Pontificia Universidad Católica de Valparaíso, pp. 117-138.

Rıoseco Enríquez, Emilio (2004), "Precisiones sobre la excepción de contrato no cumplido", en: Revista Actualidad Jurídica (№ 10), pp. 295-298.

Rodríguez Grez, Pablo (2004): "Sobre la excepción de contrato no cumplido", en: Revista Actualidad Jurídica (No 9), pp. 121-130

— (2004), "A propósito de la excepción de contrato no cumplido", en: Revista Actualidad Jurídica (№ 10), pp. 299-302.

\section{JURISPRUDENCIA CITADA}

Palacios con Inversiones Pingeral Ltda. (2014): Corte Suprema 10 junio 2014 (Apelación juicio ordinario de resolución de contrato), en: www. legalpublishing.cl, No identificador CL/JUR/3205/2014; 70620.

Freire con Pino (2013): Corte Suprema 9 septiembre 2013 (juicio ordinario de resolución de contrato de promesa de compraventa) en www.legalpublishing. Cl, $\mathrm{N}^{\circ}$ identificador CL/JUR/2005/2013

Vargas con Medina (2013): Corte de Apelaciones de Rancagua 3 diciembre 2013 (apelación en juicio ordinario de indemnización de perjuicios), en: www.legalpublishing.cl, No identificador CL/JUR/2821/2013; 66924.

Traeger con Inmobiliria e Inversiones doña Gabriela y Compañía Ltda. (2012): Corte Suprema 14 marzo 2012, Rol: 3103-2012, disponible en: vlex, $\mathrm{N}^{\circ}$ identificador 436179710.

Guajardo con Cerón (2012): Corte Suprema 14 mayo 2012 (juicio ordinario de nulidad de contrato de promesa) en www.legalpublishing.cl, $\mathrm{N}^{\circ}$ identificador CL/JUR/3747/2012.

Saleh con Álvarez, Corte Suprema 13 junio 2011 (juicio ordinario de resolución de contrato), en: www.legalpublishing.cl, $\mathrm{N}^{\circ}$ identificador CL/JUR/10015/2011.

Córdova con Estándar Gold S.A. (2010): Corte Suprema 13 septiembre 2010 (juicio ordinario de resolución de contrato), en: vlex, $\mathrm{N}^{\circ}$ identificador 226090199.

Martínez con Zúñiga (2010): Corte Suprema 6 diciembre 2010 (juicio ordinario de resolución de contrato con indemnización de perjuicios), en: vlex, $\mathrm{N}^{\circ}$ identificador 333056194.

Morales con Parra (2009): Corte Suprema 19 agosto 2009 (juicio ordinario de resolución de contrato de promesa), en: www.legalpublishing.cl, $\mathrm{N}^{\circ}$ identificador Legal Publishing: 42558. 
Centro Médico Dental Santa Marte con Verdugo (2003): Corte Suprema 4 diciembre 2003 (juicio ordinario de resolución de contrato de promesa), en: www.legalpublishing.cl, No identificador LegalPublishing: 29114.

Sociedad Agrícola Santa Rosa Ltda con Capos (2002): Corte de Apelaciones de Santiago, 31 enero 2002, en: www.legalpublishing.cl, $\mathrm{N}^{\circ}$ identificador CL/ JUR/1062/2002; 23963.

Wenke y otros con Fisco (1997): Corte de Apelaciones de Santiago 21 junio 1991 (juicio ordinario de resolución de contrato), en: legalpublishing.cl, $N^{\circ}$ identificador CL/JUR/417/1991.

Aravena con Lizarralde (1931): Corte Suprema 29 julio 1931 (juicio ordinario de resolución de contrato), en: Revista de Derecho y Jurisprudencia 28 (1931) II, secc. $2^{\text {a }}$, pp. 689 y ss. 